University of Wollongong

Research Online

Faculty of Engineering and Information

Faculty of Engineering and Information

Sciences - Papers: Part A

Sciences

$1-1-2013$

Stress-strain degradation response of railway ballast stabilized with geosynthetics

Buddhima Indraratna

University of Wollongong, indra@uow.edu.au

Sanjay Nimbalkar

University of Wollongong, sanjayn@uow.edu.au

Follow this and additional works at: https://ro.uow.edu.au/eispapers

Part of the Engineering Commons, and the Science and Technology Studies Commons

Research Online is the open access institutional repository for the University of Wollongong. For further information contact the UOW Library: research-pubs@uow.edu.au 


\title{
Stress-strain degradation response of railway ballast stabilized with geosynthetics
}

\begin{abstract}
Large cyclic loading on ballasted railroad tracks is now inevitable owing to an increased demand for freight and public transport. This leads to a progressive deterioration and densification of railroad ballast and consequently to the loss of track geometry and differential settlement. Understanding these complex stress-strain and degradation mechanisms is essential to predict the desirable track maintenance cycle, as well as the design of new track. This paper presents the results of cyclic drained tests and numerical studies carried out on a segment of model railway track supported on geosynthetically reinforced railroad ballast bed. The relative performance and effectiveness of single- and dual-layer configurations of geosynthetic reinforcement was evaluated using a large-scale prismoidal triaxial chamber. Laboratory tests on unreinforced and reinforced railway track were simulated in a numerical model, and the results were then analyzed to better understand the distribution of displacements and stresses inside the railroad ballast layer. It was observed that in view of strain and breakage control, both the type of reinforcement and its layout played a vital role in improving the capacity of the track. These laboratory test findings were supported by the predictions from an advanced elastoplastic numerical analysis.
\end{abstract}

\section{Keywords}

ballast, stabilized, geosynthetics, response, degradation, strain, stress, railway

\section{Disciplines}

Engineering | Science and Technology Studies

\section{Publication Details}

Indraratna, B. \& Nimbalkar, S. (2013). Stress-strain degradation response of railway ballast stabilized with geosynthetics. Journal Of Geotechnical And Geoenvironmental Engineering, 139 (5), 684-700. 


\title{
Stress-Strain Degradation Response of Railway Ballast Stabilized with Geosynthetics
}

\author{
Buddhima Indraratna, F.ASCE ${ }^{1}$; and Sanjay Nimbalkar ${ }^{2}$
}

\begin{abstract}
Large cyclic loading on ballasted railroad tracks is now inevitable owing to an increased demand for freight and public transport. This leads to a progressive deterioration and densification of railroad ballast and consequently to the loss of track geometry and differential settlement. Understanding these complex stress-strain and degradation mechanisms is essential to predict the desirable track maintenance cycle, as well as the design of new track. This paper presents the results of cyclic drained tests and numerical studies carried out on a segment of model railway track supported on geosynthetically reinforced railroad ballast bed. The relative performance and effectiveness of single- and dual-layer configurations of geosynthetic reinforcement was evaluated using a large-scale prismoidal triaxial chamber. Laboratory tests on unreinforced and reinforced railway track were simulated in a numerical model, and the results were then analyzed to better understand the distribution of displacements and stresses inside the railroad ballast layer. It was observed that in view of strain and breakage control, both the type of reinforcement and its layout played a vital role in improving the capacity of the track. These laboratory test findings were supported by the predictions from an advanced elastoplastic numerical analysis. DOI: 10.1061/(ASCE)GT.1943-5606.0000758. @ 2013 American Society of Civil Engineers.
\end{abstract}

CE Database subject headings: Repeated loads; Soil deformation; Degradation; Geosynthetics; Geotechnical models; Railroad ballast; Railroad Tracks; Stress; Strain.

Author keywords: Repeated loads; Deformation; Degradation; Geosynthetics; Geotechnical models; Railroad ballast; Railroad tracks.

\section{Introduction}

Large countries such as the United States, Canada, China, India, and Australia rely heavily on railways for the transportation of bulk commodities and passenger services. These countries have introduced faster and heavier trains in recent years owing to a growing demand from commuters and industry. This has resulted in an increase in track degradation, lateral instability, and therefore the frequency and cost of maintenance. This problem becomes more severe under conditions of railroad ballast fouling (Selig and Waters 1994).

Particles of railroad ballast become degraded in railroad tracks under heavy cyclic loading, thereby increasing the overall compressibility (Anderson and Fair 2008; Lackenby et al. 2007; Lu and McDowell 2006; Indraratna et al. 2010a). The use of geosynthetics in railroad tracks has been studied in the past, and it has been proven that geosynthetics generally improve track performance by reducing the deformation and degradation of railroad ballast (Göbel et al. 1994; Rowe and Jones 2000; Raymond 2002; Shin et al. 2002; Brown et al. 2007; Indraratna and Salim 2003; Indraratna et al. 2006, 2007). The application of geosynthetics to granular materials both in permanent pavements and for heavy-haul roads is well known (Koerner 1990; Giroud and Han 2004a, b, Kwon et al. 2009), but

\footnotetext{
${ }^{1}$ Professor of Civil Engineering, Faculty of Engineering, Univ. of Wollongong, Wollongong City, NSW 2522, Australia (corresponding author).E-mail: indra@uow.edu.au

${ }^{2}$ Research Fellow, Faculty of Engineering, Univ. of Wollongong, Wollongong City, NSW 2522, Australia.

Note. This manuscript was submitted on September 7, 2011; approved on July 11, 2012; published online on April 15, 2013. Discussion period open until October 1, 2013; separate discussions must be submitted for individual papers. This paper is part of the Journal of Geotechnical and Geoenvironmental Engineering, Vol. 139, No. 5, May 1, 2013. (CASCE, ISSN 1090-0241/2013/5-684-700/\$25.00.
}

only limited studies have been conducted on railroad ballast that is significantly coarser (Selig and Waters 1994; Indraratna et al. 2011).

In addition, only limited studies have focused on the fundamentals of interaction between grids and ballast aggregates under large strain conditions when subjected to cyclic loading. A numerical model that can capture the envelope of the maximum plastic deformations generated during individual load cycles and that facilitates the prediction of accumulated deformation at a large number of load cycles is usually adequate for railroad track practice (Suiker and de Borst 2003). Moreover, the development of practical and reliable design methods and the correct grid specifications for particular applications has not been as soundly based (Brown et al. 2007). It is desirable to optimize performance and provide a background to improve railroad track design. Extensive laboratory experiments were conducted on fresh and recycled railroad ballast under both dry and wet conditions to investigate the effectiveness of three types of geosynthetics [geogrid, woven geotextile, and geocomposite (geogrid + nonwoven geotextile)] using a large-scale prismoidal test chamber (Indraratna and Salim 2003; Indraratna et al. 2006, 2007). Various types of geosynthetic reinforcements placed in unbound ballast have usually improved the performance of rail transportation systems, but unfortunately, the optimal location and number of geogrid layers have not been established. A few recent studies have attempted to analyze the effects of multiple geosynthetic reinforcement through model studies (Raymond and Ismail 2003; Jiroušek et al. 2010) and full-scale field trials (Montanelli and Recalcati 2003).

This paper presents the results of cyclic loading tests and numerical studies conducted on fresh railroad ballast stabilized with three types of geosynthetics (geogrid, nonwoven geotextile, and geocomposite) for single- and double-reinforcement arrangements. The model tests were conducted using a large-scale prismoidal triaxial chamber that was designed and built at the University of Wollongong. The lateral displacement of railroad ballast in the field is not restricted (in the absence of sufficient confining pressure); hence the prismoidal triaxial chamber with unrestrained sides 
provides an ideal facility for physical modeling of the deformations of railroad ballast under cyclic loading (Indraratna and Salim 2003; Indraratna et al. 2006, 2007). The primary objective of this study was to evaluate the deformation and degradation of railroad ballast under a large number of cycles and to study the influence of the type and tensile stiffness of the reinforcement on the overall performance of the railroad ballast. However, laboratory tests alone do not provide incisive and cost-effective means to gain a full insight into the complex mechanisms of breakage and associated stress deformation characteristics of railroad ballast at intermediate load cycles. Therefore, a numerical analysis (FEM) was carried out by implementing an extended elastoplastic constitutive formulation to capture particle breakage, as well as the effect of geosynthetic reinforcement on the stress-strain behavior of railroad ballast during cyclic loading. The shear and volumetric deformation mechanisms in the granular substructure are both of a plastic nature (i.e., they are activated after a certain level of stress has been exceeded, and the magnitude of these strains remains relatively constant as soon as unloading occurs).

\section{Experimental Study}

\section{Materials Used for Testing}

\section{Ballast, Subballast, and Clay Subgrade}

The fresh railroad ballast used in the present investigation is latite basalt, a common aggregate obtained from a designated quarry in Bombo (near Wollongong city), Australia. The ballast particles represent sharp angular coarse aggregates, and their required physical properties (Indraratna et al. 1998) were evaluated using the standard test procedures as per AS2758.7 (Standards Australia 1996). Latite basalt is a fine-grained, very dark, and dense aggregate that contains the essential minerals plagioclase (feldspar) and augite (pyroxenes). The selected particle size distributions (PSDs) of fresh ballast, subballast, and subgrade materials were based on current industry practice (Standards Australia 1996; Rail Infrastructure Corporation of New South Wales 2001a, b), as shown in Fig. 1. Sieve analysis was conducted on the material retained on the No. 200 sieve, and a Malvern particle size analyzer was employed for the finer fraction (particle size $<0.075 \mathrm{~mm}$ ). A thin layer of compacted clayey sand was used in the laboratory model to simulate the subgrade

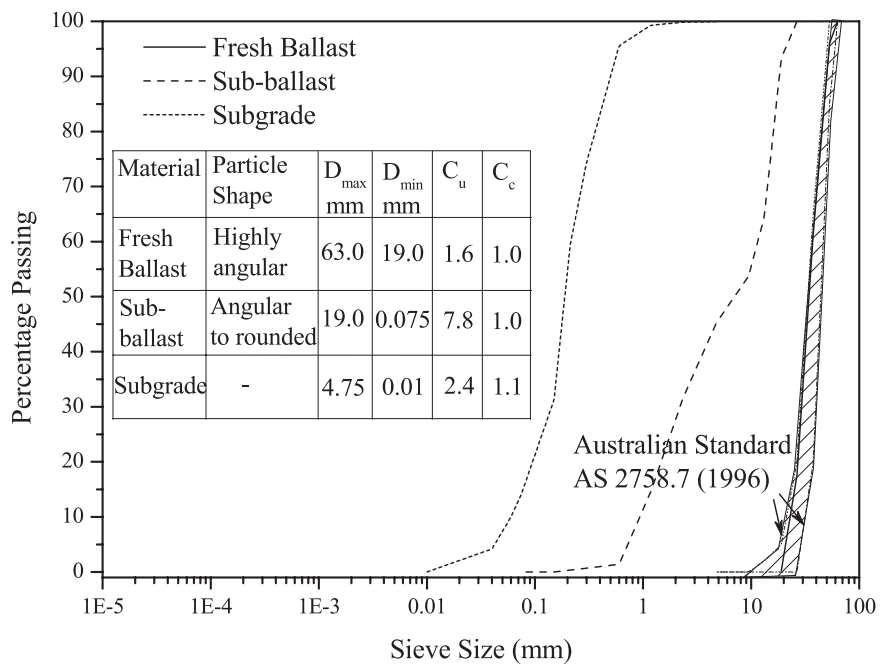

Fig. 1. Particle size distributions of fresh ballast, subballast, and subgrade materials of a real railroad track. A subballast layer comprised a sand-gravel mixture.

\section{Geosynthetics}

Three types of geosynthetics were used in the laboratory test chamber to stabilize the fresh railroad ballast. These included (1) biaxial geogrid, (2) nonwoven geotextile, and (3) geocomposite, which is a combination of biaxial geogrid and nonwoven geotextile. The physical and mechanical characteristics of these geosynthetics are described in Table 1. Cubical triaxial tests reported by Indraratna et al. (2011) indicated that a layer of geocomposite (i.e., geogrid bonded with nonwoven geotextiles) stabilized recycled ballast

Table 1. Index Properties of Geosynthetic Materials [Techfab Industries, Ltd. (India)]

\begin{tabular}{|c|c|c|}
\hline Geosynthetic type & Geogrid & Geotextile \\
\hline Material & Polyester & Polypropelene \\
\hline Structure & Biaxial & Nonwoven \\
\hline \multicolumn{3}{|l|}{ Mechanical } \\
\hline \multicolumn{3}{|l|}{ Ultimate tensile strength } \\
\hline \multicolumn{3}{|l|}{$(\mathrm{kN} / \mathrm{m})$} \\
\hline Machine direction & $40^{\mathrm{a}}$ & - \\
\hline Cross-machine direction & $40^{\mathrm{a}}$ & \\
\hline \multicolumn{3}{|l|}{$\begin{array}{l}\text { Tensile strength at } 2 \% \text { strain } \\
(\mathrm{kN} / \mathrm{m})\end{array}$} \\
\hline Machine direction & $9^{\mathrm{a}}$ & - \\
\hline Cross-machine direction & $9^{\mathrm{a}}$ & \\
\hline \multicolumn{3}{|l|}{$\begin{array}{l}\text { Tensile strength at } 5 \% \text { strain } \\
(\mathrm{kN} / \mathrm{m})\end{array}$} \\
\hline Machine direction & $18^{\mathrm{a}}$ & - \\
\hline Cross-machine direction & $18^{\mathrm{a}}$ & \\
\hline Grab tensile strength $(\mathrm{N})$ & - & $1,570^{\mathrm{c}}$ \\
\hline Trapezoidal tear $(\mathrm{N})$ & - & $600^{\mathrm{d}}$ \\
\hline Puncture strength (N) & - & $910^{\mathrm{e}}$ \\
\hline Mullen burst (kPa) & - & $4,700^{\mathrm{f}}$ \\
\hline \multicolumn{3}{|l|}{ Elongation at break (\%) } \\
\hline Machine direction & $15^{\mathrm{a}}$ & $60^{\mathrm{c}}$ \\
\hline Cross-machine direction & $15^{\mathrm{a}}$ & \\
\hline \multicolumn{3}{|l|}{ Hydraulic } \\
\hline $\begin{array}{l}\text { Permeability/flow rate } \\
\left(\mathrm{L} / \mathrm{m}^{2} / \mathrm{s}\right)\end{array}$ & - & $35^{\mathrm{g}}$ \\
\hline Apparent opening size, & - & $90^{\mathrm{h}}$ \\
\hline \multicolumn{3}{|l|}{$\operatorname{AOS}(\mu \mathrm{m})$} \\
\hline \multicolumn{3}{|l|}{ Endurance } \\
\hline Ultraviolet resistance & - & $70^{\mathrm{i}}$ \\
\hline \multicolumn{3}{|l|}{ @ $500 \mathrm{~h}(\%)$} \\
\hline \multicolumn{3}{|l|}{ Physical } \\
\hline \multicolumn{3}{|l|}{ Aperture size (mm) } \\
\hline Machine direction & 40 & - \\
\hline Cross-machine direction & 40 & \\
\hline Thickness (mm) & - & $2.9^{\mathrm{j}}$ \\
\hline Mass per unit area $\left(\mathrm{g} / \mathrm{m}^{2}\right)$ & $390^{\mathrm{b}}$ & $500^{\mathrm{k}}$ \\
\hline \multicolumn{3}{|l|}{ aASTM D6637 (ASTM 2001a). } \\
\hline \multicolumn{3}{|l|}{ b ASTM D5261 (ASTM 2003b). } \\
\hline \multicolumn{3}{|l|}{ cASTM D4632 (ASTM 2003a). } \\
\hline \multicolumn{3}{|l|}{ d ASTM D4533 (ASTM 2004b). } \\
\hline \multicolumn{3}{|l|}{${ }^{\mathrm{e}}$ ASTM D4833 (ASTM 2001c). } \\
\hline \multicolumn{3}{|l|}{${ }^{\mathrm{f}}$ ASTM D3786 (ASTM 2001b). } \\
\hline \multicolumn{3}{|l|}{${ }^{\mathrm{g}}$ ASTM D4491 (ASTM 2004c). } \\
\hline \multicolumn{3}{|l|}{ h'ASTM D4751 (ASTM 2004a). } \\
\hline \multicolumn{3}{|l|}{${ }^{\mathrm{i}}$ ASTM D4355 (ASTM 1999). } \\
\hline \multicolumn{3}{|l|}{ jaSTM D5199 (ASTM 2006). } \\
\hline kASTM D5261 (ASTM 2003b). & & \\
\hline
\end{tabular}


much better than standard geogrids. In a geocomposite, the geogrid provides a strong mechanical interlock with the angular particles of ballast (reinforcement), whereas the nonwoven geotextile prevents the fines from moving up from the layers of subballast and subgrade, thus keeping the ballast layer relatively clean.

\section{Laboratory Model Tests}

\section{Test Setup}

The large-scale prismoidal triaxial chamber used in this study can accommodate specimens $800 \mathrm{~mm}$ long, $600 \mathrm{~mm}$ wide, and $600 \mathrm{~mm}$ high [Fig. 2(a)]. To model real railroad track, the prismoidal test chamber was filled in four layers. This is a true triaxial apparatus in which three independent principal stresses can be applied in three mutually orthogonal directions. Because each wall of the test chamber can move independently in a lateral direction, the ballast specimen is free to deform laterally under cyclic vertical load and lateral pressures. Although the actual stress states may not be simulated exactly, especially near the lateral boundaries, this particular chamber reasonably simulates realistic track boundary conditions (Indraratna and Salim 2003). Cyclic vertical stresses were measured using pressure cells made of stainless steel (12 mm thick, $230 \mathrm{~mm}$ in diameter) installed at the tie-ballast and ballast-capping interfaces. To measure vertical and horizontal deformations of the ballast, settlement pegs (consisting of $100-\times 100-\times 6$-mm stainless steel base plates attached to 10 -mm-diameter stainless steel rods) and

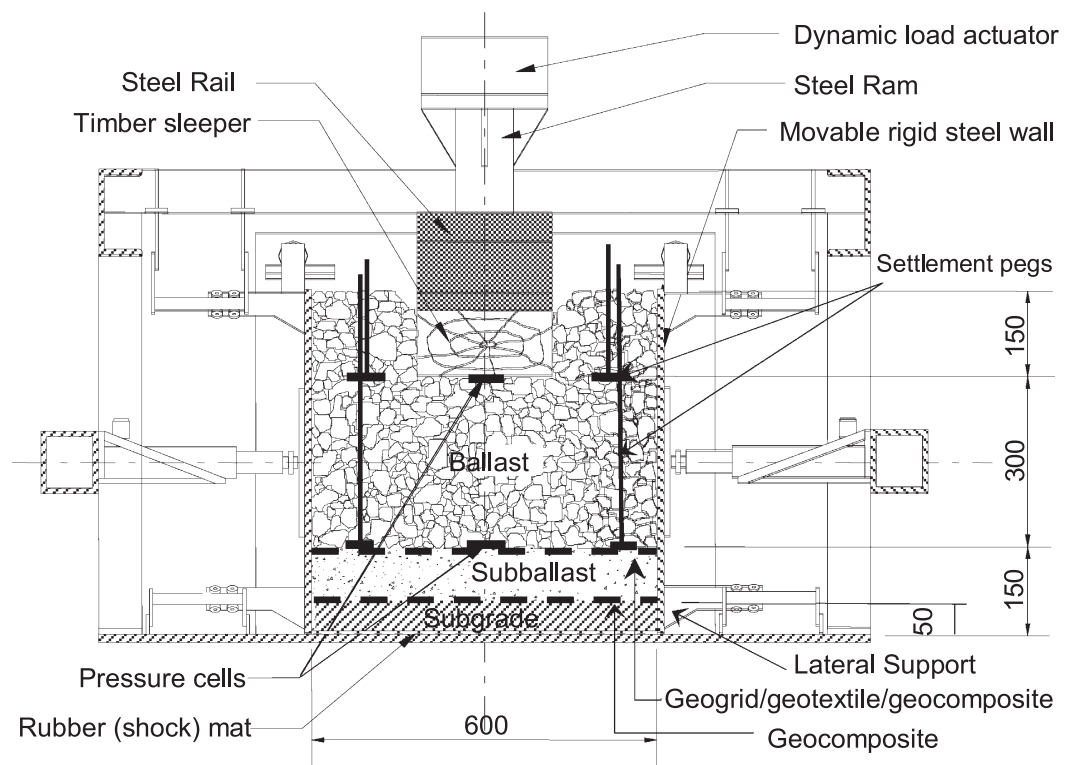

(a)

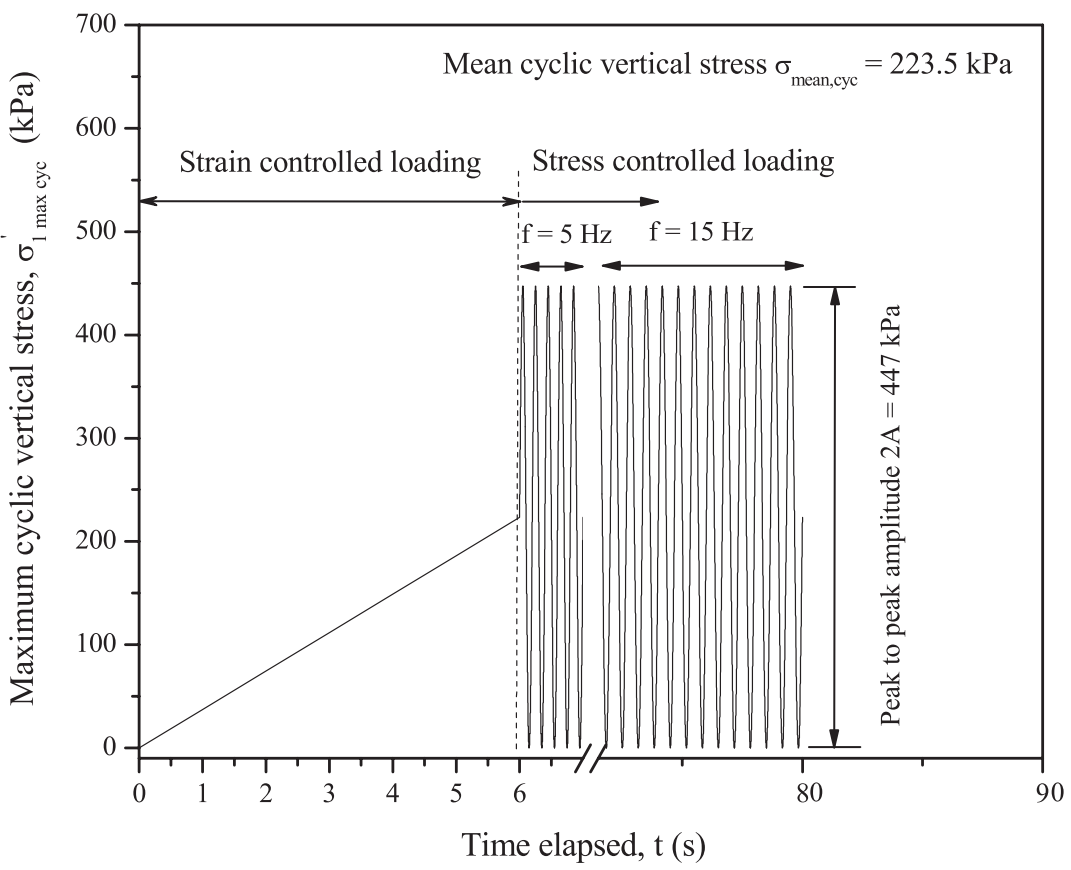

(b)

Fig. 2. (a) Schematic illustration of cyclic triaxial chamber; (b) details of cyclic loading 
electronic potentiometers were installed in different track sections, respectively [Fig. 2(a)].

\section{Preparation of Test Specimens}

The bottom layer consisted of 50-mm-thick compacted clayey sand to simulate the layer of subgrade soil under the track. A 100-mmthick mixture of compacted gravel and sand was used to represent the subballast layer. The upper two layers, viz. load-bearing ballast (300 mm thick) and crib ballast (150 mm thick), consisted of fresh ballast. A timber tie and rail segment was placed above the compacted load-bearing layer of ballast, and the space between the tie and walls was filled with crib ballast. The 300 -mm-thick layer of ballast was compacted in four 75-mm-thick layers and the subballast (100 mm thick) was compacted in two 50-mm-thick layers to achieve representative field densities. The compaction was carried out using a vibratory hammer. The subballast was compacted close to optimal moisture content of $8.35 \%$ [maximum dry density (MDD) = $2,240 \mathrm{~kg} / \mathrm{m}^{3}$; relative compaction $(\mathrm{RC})=96 \%$; specific gravity $\left.\left(G_{s}\right)=2.6\right]$. The subgrade was compacted close to an optimal moisture content of $12.64 \%\left(\mathrm{MDD}=1,930 \mathrm{~kg} / \mathrm{m}^{3} ; \mathrm{RC}=98 \%\right.$; $\left.G_{s}=2.68\right)$. The bulk unit weights $\left(\gamma_{\text {bulk }}\right)$ of the compacted layers of ballast, subballast, and subgrade were $15.3,23.8$, and $21.4 \mathrm{kN} / \mathrm{m}^{3}$, respectively. The corresponding initial void ratios $\left(e_{0}\right)$ of the ballast and subballast layers were 0.74 and 0.52 , respectively.

\section{Layout of Geosynthetics in Test Specimens}

Single-Layer Arrangement. The relative benefits of different geosynthetics-(1) biaxial geogrid, (2) nonwoven geotextile, and (3) geocomposite-when placed as a single layer at the ballastsubballast interface, were then evaluated. In real railroad track, the depth of this placement (about $300 \mathrm{~mm}$ from the base of the tie) is enough to prevent any damage from the tamper tines.

Dual-Layer Arrangement. Apart from the biaxial geogrid and the nonwoven geotextile placed at the ballast-subballast interface, as described earlier, the layer of geocomposite was placed at the underlying subballast-subgrade interface to evaluate the added benefits of a dual-layer arrangement.

\section{Testing Procedure}

A cyclic vertical stress $\left(\sigma_{1 \text { cyc }}^{\prime}\right)$ was provided by a servohydraulic actuator and transmitted to the ballast through a 100 -mm-diameter steel ram and a rail-tie assembly. In railroad track environments, the confining pressure is of major concern (Lackenby et al. 2007). Under normal railroad track environments, a significant lateral movement is observed in the ballast layer owing to reduced lateral restraint at the edge of sleeper (Indraratna et al. 2010a, 2011). To simulate track behavior under low-field confinement, small lateral pressures (intermediate principal stress $\sigma_{2}^{\prime}=10 \mathrm{kPa}$, and minor principal stress $\sigma_{3}^{\prime}=7 \mathrm{kPa}$ ) were applied to the triaxial specimens through hydraulic jacks to simulate field confinement. Confinement in a real railroad track generally is provided by the weight of the crib and shoulder ballast, along with a frictional interlock between particles of angular ballast and interaction between tie and ballast. Initially, a strain-controlled test was performed (at a rate of $1 \mathrm{~mm} / \mathrm{s}$ ) until the mean level of cyclic deviator stress was reached. Afterward, a stresscontrolled test with a harmonic sinusoidal cyclic stress amplitude of $\Delta \sigma_{1 \text { cyc }}^{\prime}=\sigma_{1 \text { max,cyc }}^{\prime}-\sigma_{1 \text { min,cyc }}^{\prime}$ was carried out [Fig. 2(b)]. A reducedfrequency conditioning phase $(5 \mathrm{~Hz})$ was employed at the commencement of cyclic loading (during rapid vertical deformation) to prevent impact loading and loss of actuator contact with the top surface of the rail-tie assembly. After this stage, initial readings of load cells, potentiometers, and settlement plates were taken, and then a cyclic load with a maximum intensity $\left(\sigma_{1 \text { max,cyc }}^{\prime}\right)$ corresponding to
25 tons/axle load calculated in accordance with American Railway Engineering Association (AREA) method (Li and Selig 1998) was applied. The tests were conducted at a frequency of $15 \mathrm{~Hz}$, which simulated a speed of $109 \mathrm{~km} / \mathrm{h}$, a wheel diameter of $0.97 \mathrm{~m}$, and an assumed distance between the wheels of common rolling stock bogies of $2.02 \mathrm{~m}$. The average contact stress at the tie-ballast interface obtained by the AREA method was $447 \mathrm{kPa}$ compared with $335 \mathrm{kPa}$ using the European method (Esveld 2001). The total number of load cycles applied in each test was 200,000. The cyclic loading was halted at a selected number of cycles, and readings of settlement, lateral movement of walls, and loading magnitudes were recorded. Initial cyclic triaxial experiments with and without a rest period indicate that a rest period has an insignificant influence on ballast deformation with the number of cycles (Indraratna et al. 2010b). Six tests were conducted to investigate the response of cyclic loading on railroad ballast with and without geosynthetics. Initially, the deformation of model railroad track with the singlereinforcement configuration was analyzed through a series of tests, whereas the effect of a double-reinforced model railroad track was studied in terms of strain and breakage control.

\section{Results and Discussion}

\section{Settlement Characteristics}

The vertical deformation (and strains) of railroad ballast were computed by excluding the deformation of the layers of subballast and subgrade and are shown in Fig. 3(a). In this respect, the limited thickness of the layer of subgrade was expected to have an insignificant influence on the test results, especially when compared with the response of different ballast specimens with and without geosynthetics (Indraratna et al. 2007). As expected, the ballast deformed rapidly when the loading cycles commenced, although its rate of settlement diminished to a controlled steady state after a certain level of load repetitions had passed, defined as the stable zone [Fig. 3(a)]. The granular materials display a strong tendency to compact under cyclic loading (Lackenby et al. 2007; Indraratna et al. 2010a, b). As evident from Fig. 3(a), ballast settlement is characterized by three phases. The first phase is the immediate settlement under the first loading cycle. The second phase is an unstable zone where rapid settlement occurs. Reorientation and rearrangement of particles along with significant breakage generate a denser (compressive) packing assembly. In the third phase, the rate of increase of settlement is marginal, with an almost linear relationship between settlement and the number of load cycles. This third phase is often characterized as stable shakedown. Thus the ballast settlement $S_{N}$ can be modeled in terms of the number of load cycles $N$ as

$$
S_{N}=S_{1}\left(1+a \ln N+0.5 b \ln N^{2}\right)
$$

where $S_{1}=$ settlement of ballast after the first load cycle, and $a$ and $b=$ two empirical constants. The first term in Eq. (1) refers to settlement owing to the first cycle, the second to an unstable zone $\left(N<10^{4}\right.$ cycles), and the third term to a stable shakedown zone ( $N>10^{4}$ cycles). The settlement of ballast was plotted on a normal scale with a comparison with different settlement models, as shown in Fig. 3(a). These settlement models and their regression parameters are described in Table 2 . The parameters $a$ and $b$ were determined by the new equation proposed here [Eq. (1)]. Other parameters $c$ to $y$ were determined by using solutions proposed by others [Table 2; Fig. 3(a)].

Compared with unreinforced ballast, reinforced ballast exhibited a lower vertical settlement [Fig. 3(b)]. In every laboratory test, the geosynthetic reinforcement remained intact. This occurred because 


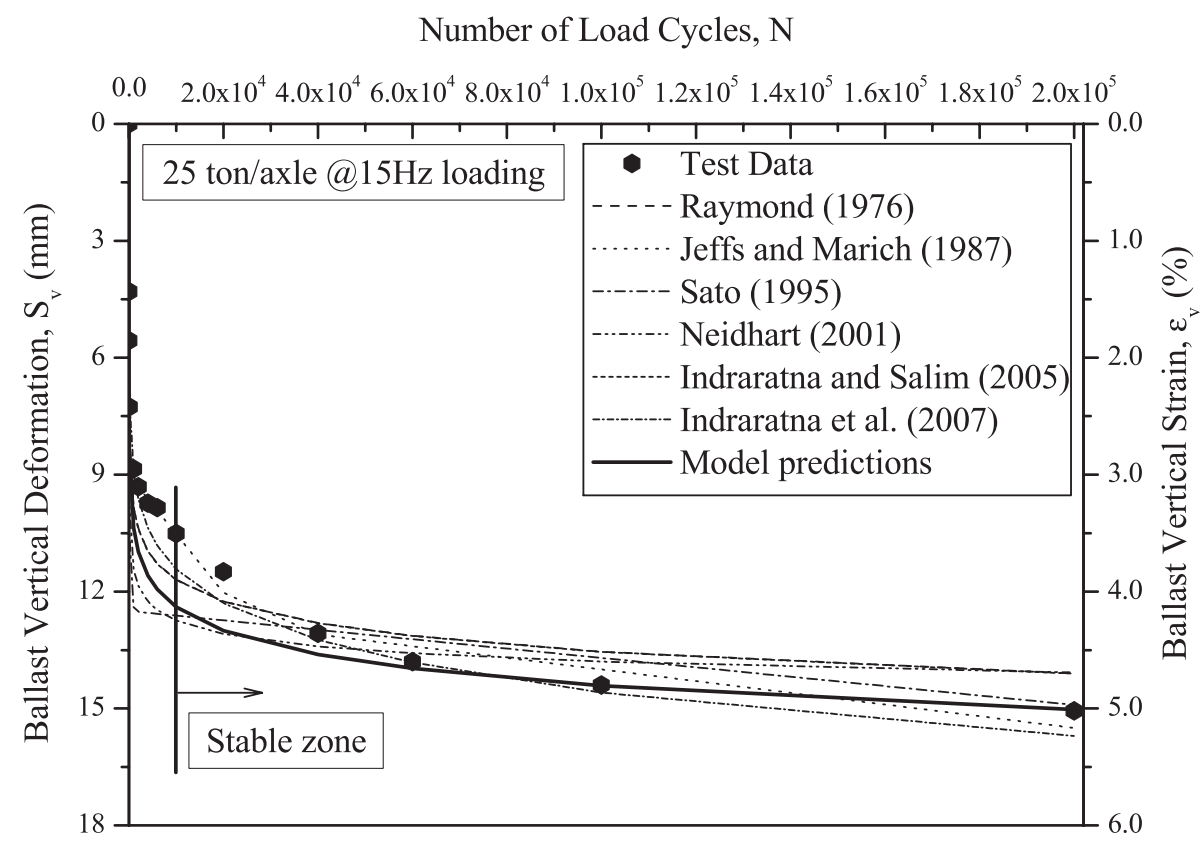

(a)

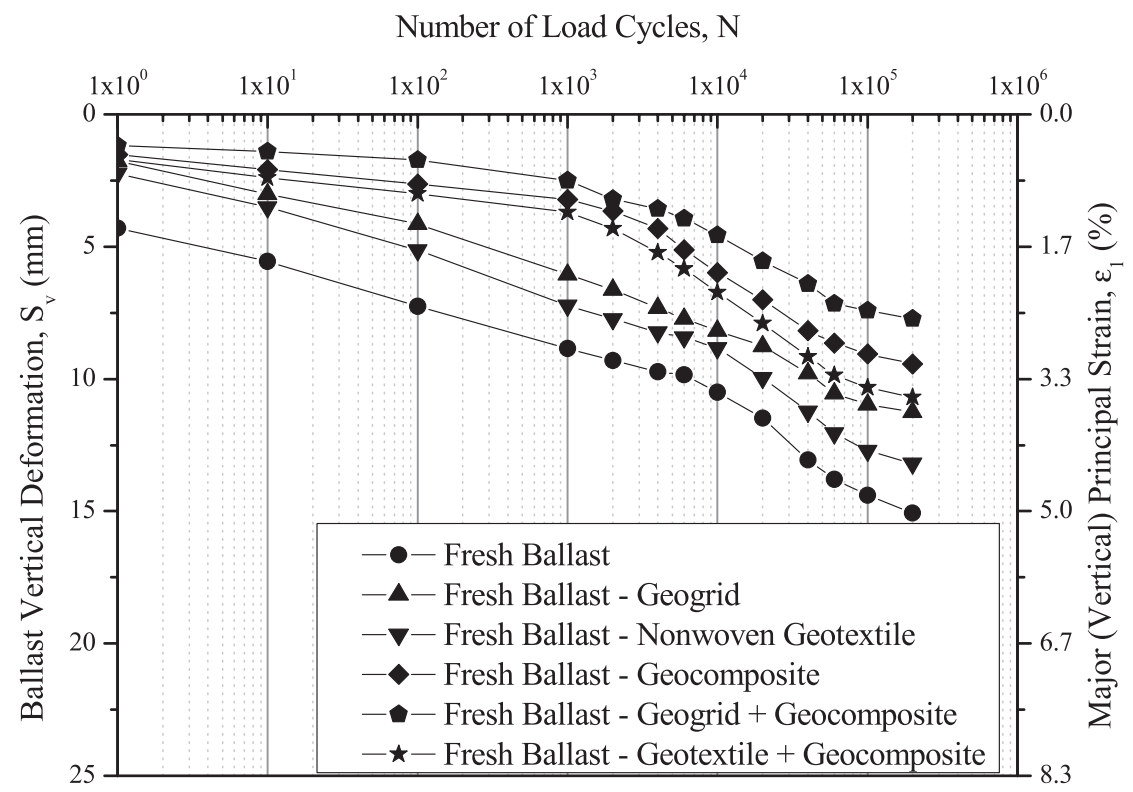

(b)

Fig. 3. Vertical deformation of fresh ballast: (a) comparison with previous studies; (b) that with and without geosynthetics plotted in semilogarithmic scale

the mechanism of reinforcement is truly the aggregate-geogrid interlock causing the local stiffness increase, and it is not related to differences in tensile strength of stiff (extruded) geogrids. The geogrid appeared to be more effective than the nonwoven geotextile. This may be attributed to the fact that highly frictional angular particles of fresh ballast develop a strong mechanical interlock with the geogrid, whereas the performance of geotextile depends largely on its tensile membrane action. As expected, the fresh ballast stabilized with the geocomposite (a combination of geogrid and geotextile) exhibited the least vertical settlement. This occurred because a nonwoven geotextile offers an optimal separation between the layers of ballast and subballast while maintaining a higher resiliency, whereas a biaxial geogrid provides a strong interlock. The pattern of the settlement logarithm of numbers of load cycles for the doubly reinforced case was similar to that of the single reinforced tests [Fig. 3(b)]. They all portrayed a curved nonlinear pattern on a semilogarithmic plot. In all cases, the benefit of geogrid reinforcement was more significant when the test specimens were subjected to higher numbers of loading cycles. The doubly reinforced case showed considerable beneficial effects on the cumulative plastic settlement. The dual-layer reinforcement (geogrid and geocomposite) of the uniform ballast aggregates appeared to have the greatest beneficial effect in reducing settlement. The response of the reinforced section is related to the shear resistance mobilized at the interface owing to interaction between the geogrid, ballast, and subballast. The shear resistance mobilized at the interface provides additional internal confinement by interlocking with aggregates, and deflection induces a tension-membrane effect in the geogrid. 
Table 2. Models Linking Permanent Deformation to the Number of Load Cycles

\begin{tabular}{|c|c|c|c|}
\hline Equation number & Model & Reference & Regression parameters \\
\hline $\mathrm{i}$ & $S_{N}=S_{1}(1+a \log N)$ & Raymond et al. (1975) & $a$ \\
\hline ii & $S_{N}=g+h(\log N)+k N \quad$ for $N \leq 200,000$ & Jeffs and Marich (1987) & $g, h, i, j, k$ \\
\hline iii & $\begin{array}{c}S_{N}=i+j N \quad \text { for } N>200,000 \\
S_{N}=\gamma\left(1-e^{-\alpha N}\right)+\beta N \\
e \log N\end{array}$ & Sato (1995) & $\alpha, \beta, \gamma$ \\
\hline iv & $S_{N}=S_{1}+\frac{e \log N}{1+f \log N}$ & Neidhart (2001) & $e, f$ \\
\hline $\mathrm{v}$ & $S_{N}=S_{1}\left(N^{y}\right)$ & Indraratna et al. (2007) & $y$ \\
\hline vi & $S_{N}=c+d(\ln N)$ & Indraratna et al. (2011) & $c, d$ \\
\hline vii & $S_{N}=S_{1}\left(1+a \ln N+0.5 b \ln N^{2}\right)$ & Present study & $a, b$ \\
\hline
\end{tabular}

\section{Strain Characteristics}

Under repeated loading, the specimens of railroad ballast undergo compression in the vertical direction (major principal strain $\varepsilon_{1}$ ) and expand in the two lateral directions (intermediate principal strain $\varepsilon_{2}$ and minor principal strain $\varepsilon_{3}$ ). Fig. 3(b) also shows a variation in the major principal strain $\varepsilon_{1}$ of fresh ballast under an increasing number of load cycles with and without geosynthetics. The variations in the lateral strains $\left(e_{2}, e_{3}\right)$ of fresh ballast with and without geosynthetics are shown in Figs. 4(a and b). It is important to note that these lateral strains are based on the rigid-body movements of the walls of the prismoidal triaxial chamber, and therefore, they only represent the average strains across the depth of the sample, not at the interface (in particular, the ballast-subballast or subballast-subgrade interface), where the lateral strains were expected to be the least or even negligible owing to placement of the geosynthetics.

The geogrid decreased the lateral strain of the ballast by an appreciable amount, thus proving to be more effective than the geotextile. The geogrid provided internal confinement (lateral stability) to the ballast layer, thus improving its vertical stress distribution characteristics. Confinement was achieved by the geogrid restraining the lateral and vertical deformation of the ballast layer. Part of the ballast layer located in the immediate vicinity of the geogrid became locked into the aperture of the geogrid during placement and compaction of the ballast particles. The reinforcement action of the geogrid is generated by the application of vertical stress, and it is responsible for the reduction in lateral and vertical deformations of the ballast. Furthermore, introducing two layers of geosynthetic reinforcement had a pronounced effect on controlling the lateral strain in the ballast. Fresh ballast stabilized with geocomposites or geogrids exhibited less lateral strain $\left(e_{3}\right)$ than fresh ballast (without any geosynthetics) at a higher number of load cycles. This result has a significant bearing on the maintenance of railroad tracks because reducing the lateral movement of ballast with the inclusion of geocomposites implies a reduced need for additional layers of crib and shoulder ballast during maintenance operations.

\section{Ballast Breakage}

The degree of particle crushing affects the deformation and ultimate strength characteristics of railroad ballast materials (Selig and Waters 1994; Indraratna et al. 1998, 2011). Initially, local crushing at the interparticle contacts takes place, followed by the complete fracture of weaker particles when the load is increased further. This breakage of the grain contributes to differential track settlement and increasing vertical and lateral deformations. To analyze the degradation of fresh ballast under cyclic loading, an assessment of ballast breakage was performed. After each test was completed, crib ballast and load-bearing ballast aggregates were recovered from the triaxial chamber separately and then sieved to determine any changes in particle gradation. The breakage was quantified using the parameter ballast breakage index (BBI), proposed by Indraratna et al. (2005). By using a hypothetical linear size axis as a reference, the BBI then was calculated using Eq. (2):

$$
\mathrm{BBI}=\frac{A}{A+B}
$$

where $A=$ shift in the particle size distribution (PSD) curve after the test, and $B=$ potential breakage. On a PSD plot, the potential breakage $B$ is defined by the area between the arbitrary boundary of maximum breakage and the final PSD curve. The BBI values obtained from all the tests are presented in Table 3. The fresh ballast stabilized with geotextile reinforcement showed marginally more degradation in this range of particle sizes compared with ballast stabilized with geogrid. This also explains the lower displacement of ballast when it was reinforced with geogrid. As expected, the geocomposite was the most effective at reducing ballast breakage. It was further observed that the double reinforcement was better than the single reinforcement in terms of reducing ballast breakage.

\section{Shear Strain and Volumetric Strain}

The shear strain $\varepsilon_{s}$ and volumetric strain $\varepsilon_{v}$ of the ballast can be determined by (Timoshenko and Goodier 1970)

$$
\begin{gathered}
\varepsilon_{s}=\frac{\sqrt{2}}{3}\left[\sqrt{\left(\varepsilon_{1}-\varepsilon_{2}\right)^{2}+\left(\varepsilon_{2}-\varepsilon_{3}\right)^{2}+\left(\varepsilon_{3}-\varepsilon_{1}\right)^{2}}\right] \\
\varepsilon_{v}=\varepsilon_{1}+\varepsilon_{2}+\varepsilon_{3}
\end{gathered}
$$

where $\varepsilon_{1}=$ vertical strain (major principal strain), $\varepsilon_{2}=$ lateral strain acting parallel to the rail (intermediate principal strain), and $\varepsilon_{3}=$ lateral strain acting parallel to the tie (minor principal strain). Figs. 5(a and b) show the variation of $\varepsilon_{s}$ and $\varepsilon_{v}$ against the number of load cycles $N$. In general, both the shear strain and the volumetric strain accumulated steadily with an increasing number of cycles; however, their rates of increase were reduced with progressive accumulations of strain. Less permanent strains (shear and volumetric strains) were induced in the ballast bed reinforced with single and double layers of geosynthetics.

\section{Stress-Dilatancy Approach}

Based on an analogy between the irregular packing of soil particles and a regular assembly of spheres (or cylinders) and on the principal 


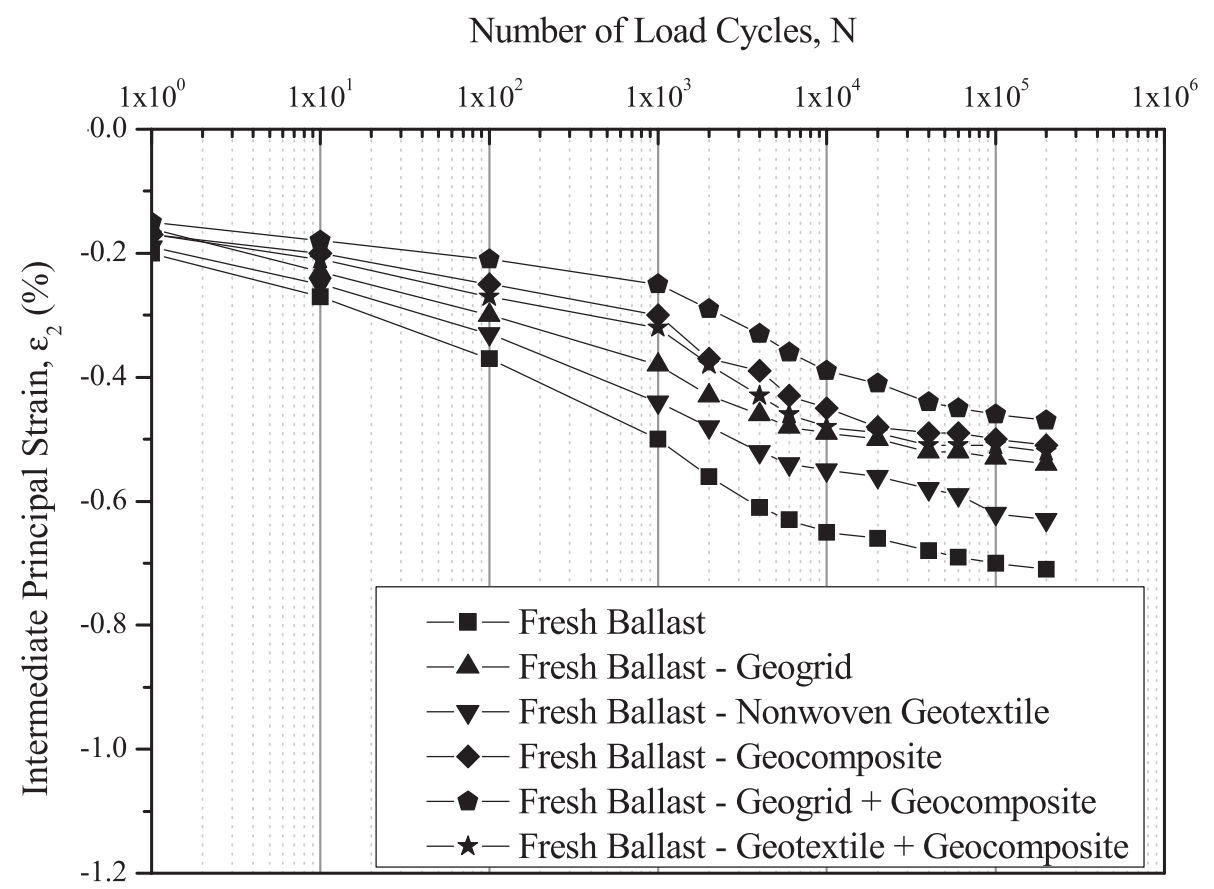

(a)

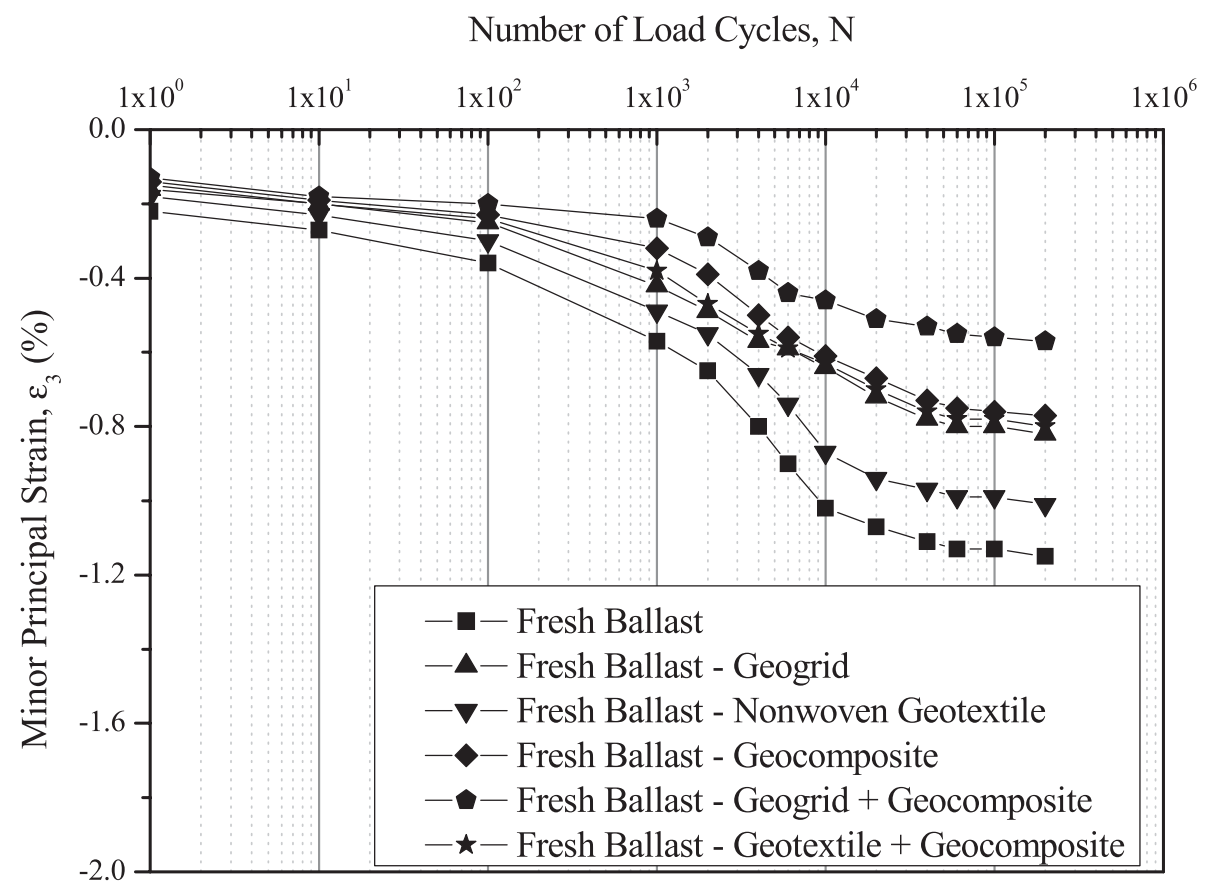

(b)

Fig. 4. Principal strains of fresh ballast layer with and without geosynthetics: (a) intermediate; (b) minor

of a minimum energy ratio, the generalized stress-dilatancy relationship can be written as (Rowe 1962)

$$
K=\frac{R}{D}
$$

where $R=$ principal stress ratio $\left(R=\sigma_{1}^{\prime} / \sigma_{3}^{\prime}\right), D=$ dilatancy $\left(D=d v / d \varepsilon_{1} ; d v / d \varepsilon_{1}\right.$ is the dilatancy rate, where $d \varepsilon_{v}$ and $d \varepsilon_{1}$ are the increments of volumetric and axial strain, respectively), and $K=$ material parameter expressed as

$$
K=\tan ^{2}\left(45+\frac{\phi_{f}^{\prime}}{2}\right)
$$

where $\phi_{f}^{\prime}=$ interparticle frictional angle. The value of $\phi_{f}^{\prime}$ varies between $\phi_{\mu}^{\prime}$ (the basic friction angle between particles) and $\phi_{c y}^{\prime}$ (the critical-state friction angle) depending on the density of the sample. By extending the approach adopted by Schanz and Vermeer (1996), as shown in Fig. 6, the following three-dimensional (3D) stressdilatancy relationship can be proposed: 
Table 3. Assessment of Ballast Breakage during Cyclic Loading

Ballast breakage index (BBI)

\begin{tabular}{llccc}
$\begin{array}{l}\text { Test } \\
\text { number }\end{array}$ & Material type & $\begin{array}{c}\text { Top zone, } \\
100 \mathrm{~mm} \text { thick }\end{array}$ & $\begin{array}{c}\text { Central zone, } \\
100 \mathrm{~mm} \text { thick }\end{array}$ & $\begin{array}{c}\text { Bottom zone, } \\
100 \mathrm{~mm} \text { thick }\end{array}$ \\
\hline 1 & Fresh ballast & 0.140 & 0.059 & 0.046 \\
2 & Ballast + geogrid & 0.119 & 0.030 & 0.015 \\
3 & $\begin{array}{l}\text { Ballast }+ \\
\text { geotextile }\end{array}$ & 0.093 & 0.066 & 0.031 \\
4 & $\begin{array}{l}\text { Ballast }+ \\
\text { geocomposite }\end{array}$ & 0.086 & 0.034 & 0.005 \\
5 & $\begin{array}{l}\text { Ballast + geogrid } \\
+ \text { geocomposite }\end{array}$ & 0.064 & 0.036 & 0.006 \\
6 & $\begin{array}{l}\text { Ballast }+ \\
\text { geotextile }+\end{array}$ & 0.106 & 0.020 & 0.015 \\
& & & \\
\hline
\end{tabular}

$$
\begin{aligned}
\frac{\sigma_{1}^{\prime}}{\sigma_{2}^{\prime} \sigma_{3}^{\prime}}= & {\left[\frac{1}{\sigma_{2}^{\prime}}\left(-\frac{d \varepsilon_{3}^{p}}{d \varepsilon_{1}^{p}}\right)+\frac{1}{\sigma_{3}^{\prime}}\left(-\frac{d \varepsilon_{2}^{p}}{d \varepsilon_{1}^{p}}\right)\right] \tan ^{2}\left(45+\frac{\phi_{f}^{\prime}}{2}\right) } \\
& +\frac{d E_{B}}{\sigma_{2}^{\prime} \sigma_{3}^{\prime} d \varepsilon_{1}^{p}}\left(1+\sin \phi_{f}^{\prime}\right)
\end{aligned}
$$

where $d E_{B}=$ incremental energy consumption by particle breakage per unit volume (Ueng and Chen 2000), and $d \varepsilon_{1}^{p}=$ plastic component of principal strain increment. The basic friction angle $\phi_{f}^{\prime}$ is the apparent effective friction angle $\phi_{f b}^{\prime}$ corresponding to a zero rate of particle breakage [i.e., $(d \mathrm{BBI})_{f} /\left(d \varepsilon_{1}^{p}\right)_{f}=0$ ]. The rate of energy consumption $\left(d E_{B} / d \varepsilon_{1}^{p}\right)$ can be calculated for a given $\phi_{f}^{\prime}$ according to Eq. (7) using the values of the effective stresses and dilatancy factors $d \varepsilon_{2}^{p} / d \varepsilon_{1}^{p}$ and $d \varepsilon_{3}^{p} / d \varepsilon_{1}^{p}$ at a given loading cycle. The $\left(d E_{B}\right)_{f}$ is related to the differential increment of ballast breakage index $(d \mathrm{BBI})_{f}$ corresponding to $\left(d \varepsilon_{1}^{p}\right)_{f}$ by a linear relationship as defined earlier by Indraratna and Salim (2002):

$$
\left(\frac{d E_{B}}{d \varepsilon_{1}^{p}}\right)_{f}=\kappa\left[\left(\frac{d \mathrm{BBI}}{d \varepsilon_{1}^{p}}\right)_{f}\right]
$$

where $\kappa=$ constant of proportionality. Thus, combining Eqs. (7) and (8), the nonassociated plastic flow rule incorporating the rate of particle breakage during shearing is now represented by

$$
\begin{aligned}
d \varepsilon_{v}^{p}= & {\left[1-\left(\frac{\sigma_{1}^{\prime}}{\sigma_{2}^{\prime} \sigma_{3}^{\prime}}\right) M_{\psi}\left(\frac{1-\sin \phi_{f}^{\prime}}{1+\sin \phi_{f}^{\prime}}\right)\right.} \\
& \left.+\kappa\left(\frac{d \mathrm{BBI}}{d \varepsilon_{1}^{p}}\right)\left(\frac{1}{\sigma_{2}^{\prime} \sigma_{3}^{\prime}}\right) M_{\psi}\left(1-\sin \phi_{f}^{\prime}\right)\right] d \varepsilon_{1}^{p}
\end{aligned}
$$

where

$$
M_{\psi}=\left[\frac{1}{\sigma_{2}^{\prime}}\left(1+\frac{d \varepsilon_{2}^{p}}{d \varepsilon_{3}^{p}}\right)^{-1}+\frac{1}{\sigma_{3}^{\prime}}\left(1+\frac{d \varepsilon_{3}^{p}}{d \varepsilon_{2}^{p}}\right)^{-1}\right]^{-1}
$$

By virtue of Eq. (9), the term $d \varepsilon_{v}^{p} / d \varepsilon_{1}^{p}$ depends on the stress state, plastic strain ratios, and particle breakage. The values of $d \varepsilon_{v}^{p} / d \varepsilon_{1}^{p}$ can be computed from Eq. (9) for a corresponding friction mobilization, progressive breakage, and stress-state evolution during either loading or reloading. It is evident that beyond $10^{4}$ load cycles, ballast undergoes negligible incremental rates of plastic deformations, implying negligible breakage (Fig. 4). Therefore, the FEM simulations in the current study are conducted at low values of $N$ (up to $10^{4}$ ). Eq. (1) is differentiated with respect to loading cycle $N$ to give

$$
\frac{d \varepsilon_{1}^{p}}{d N}=\varepsilon_{11}^{p}\left(\frac{a^{\prime}}{N}+\frac{b^{\prime}}{N}\right)
$$

where $\varepsilon_{11}^{p}=$ vertical plastic strain after the first loading cycle, and $a^{\prime}$ and $b^{\prime}=$ two empirical constants. Differentiating Eq. (9) with respect to $N$ gives

$$
\begin{aligned}
\frac{d \varepsilon_{v}^{p}}{d N}= & \left\{\left[\varepsilon_{11}^{p}\left(\frac{a^{\prime}}{N}+\frac{b^{\prime}}{N}\right)\right]-\left(\frac{\sigma_{1}^{\prime}}{\sigma_{2}^{\prime} \sigma_{3}^{\prime}}\right) M_{\psi}\left(\frac{1-\sin \phi_{f}^{\prime}}{1+\sin \phi_{f}^{\prime}}\right)\right. \\
& \left.\times\left[\varepsilon_{11}^{p}\left(\frac{a^{\prime}}{N}+\frac{b^{\prime}}{N}\right)\right]+\kappa\left(\frac{d \mathrm{BBI}}{d N}\right)\left(\frac{1}{\sigma_{2}^{\prime} \sigma_{3}^{\prime}}\right) M_{\psi}\left(1-\sin \phi_{f}^{\prime}\right)\right\}
\end{aligned}
$$

For axisymmetric $\left(\sigma_{2}^{\prime}=\sigma_{3}^{\prime} ; d \varepsilon_{2}^{p}=d \varepsilon_{3}^{p}\right)$ and plane-strain $\left(d \varepsilon_{2}^{p}=0\right)$ testing conditions, Eq. (10) is expressed as

$$
\begin{aligned}
\frac{d \varepsilon_{v}^{p}}{d N}= & \left\{\left[\varepsilon_{11}^{p}\left(\frac{a^{\prime}}{N}+\frac{b^{\prime}}{N}\right)\right]-\left(\frac{\sigma_{1}^{\prime}}{\sigma_{3}^{\prime}}\right)\left(\frac{1-\sin \phi_{f}^{\prime}}{1+\sin \phi_{f}^{\prime}}\right)\right. \\
& \left.\times\left[\varepsilon_{11}^{p}\left(\frac{a^{\prime}}{N}+\frac{b^{\prime}}{N}\right)\right]+\kappa\left(\frac{d B B I}{d N}\right)\left(\frac{1}{\sigma_{3}^{\prime}}\right)\left(1-\sin \phi_{f}^{\prime}\right)\right\}
\end{aligned}
$$

Figs. 7(a and b) illustrate the resilient characteristics of a typical cyclic stress-strain response and the corresponding flow rule in terms of incremental plastic strains accumulated in the ballast layer, respectively.

\section{Finite-Element Simulation}

Three-dimensional modeling can incorporate complex longitudinal stress-strain distribution and cross-anisotropic behavior but often requires numerous input parameters and significant computational power. In engineering practices, where possible, it is advantageous to simplify complex 3D problems into equivalent two-dimensional (2D) plane strain such as railroad tracks where the longitudinal strain $\left(\varepsilon_{2}\right)$ is negligible. Usually, the $2 \mathrm{D}$ strength criterion underestimates the actual strength when $\beta\left[=\left(\sigma_{2}^{\prime}-\sigma_{3}^{\prime}\right) /\left(\sigma_{1 \text { cyc }}^{\prime}-\sigma_{3}^{\prime}\right)\right]$ $>0$, where $\beta$ represents the role of intermediate stress (Matsuoka and Nakai 1982; Lade 2006). However, in this study, the 2D failure criterion still can predict the shear strength with acceptable accuracy for small $\beta$ values $(\cong 0.01)$. In this study, an elastoplastic model of a composite multilayer test sample including tie, ballast, subballast, subgrade, and geosynthetic is proposed. The response of this multilayer system to cyclic loading is considered by conducting a 2D plane-strain dynamic FEM analysis using PLAXIS (PLAXIS 2D 8.6). The modified stress-dilatancy relationship is used to capture the ballast particle degradation only during the loading-reloading stage, and it is assumed that only elastic deformations occur during unloading. A typical plane-strain test model is simulated in the FEM discretization, as shown in Fig. 8, with 15-node cubic strain elements that provide a fourth-order interpolation for displacements and 12 Gauss points for numerical integration.

Given the symmetry, only half the section of model railroad track is considered. The right and bottom boundaries are considered as absorbent (viscous) boundaries to avoid spurious reflections of 


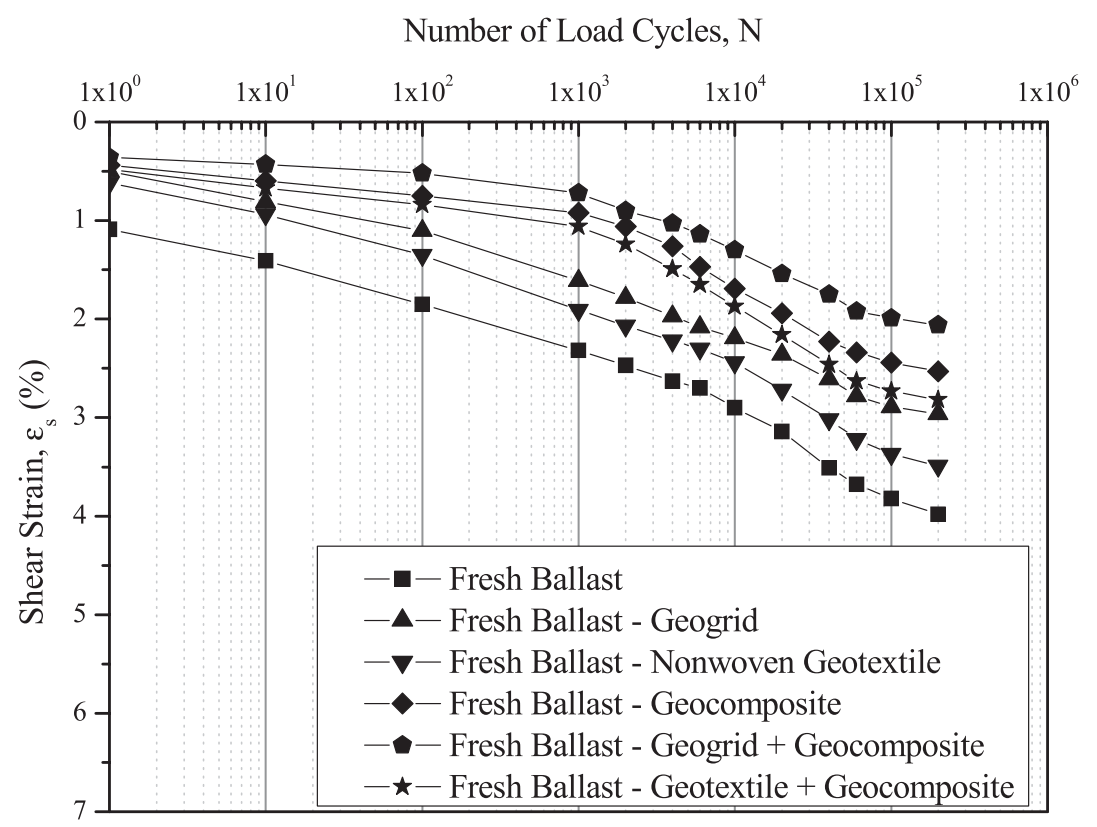

(a)

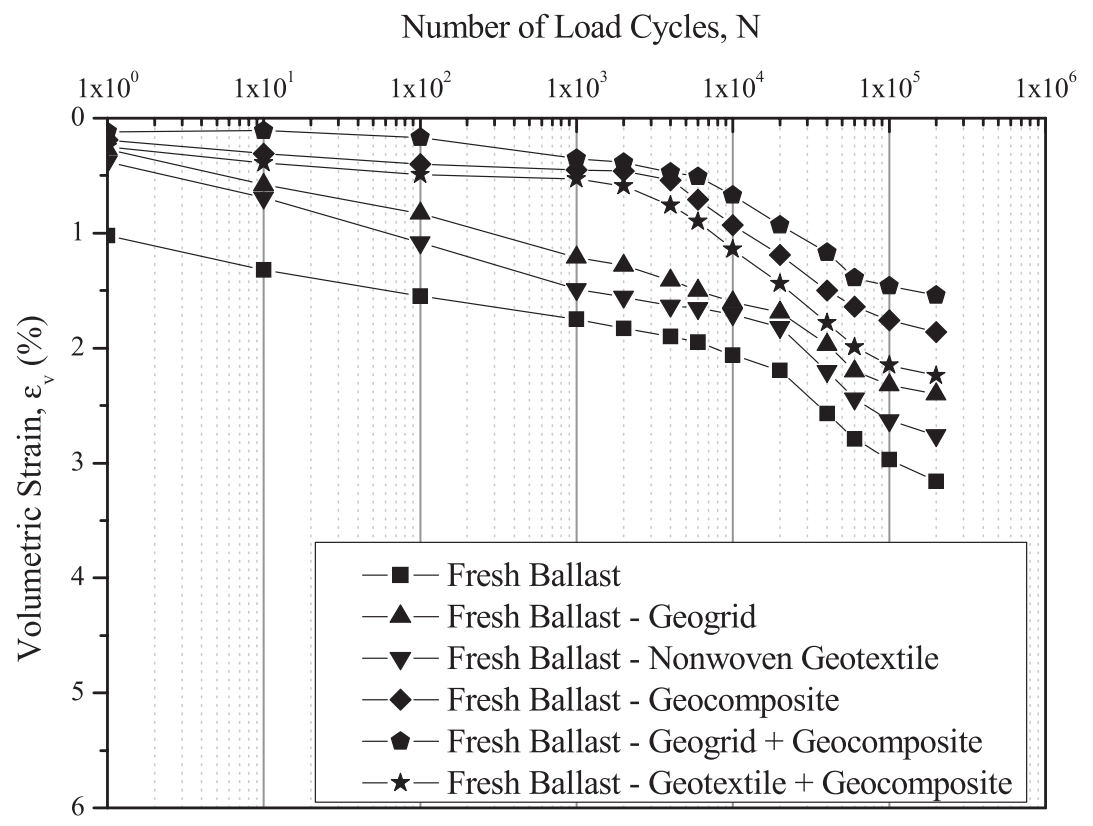

(b)

Fig. 5. (a) Shear strain; (b) volumetric strain of fresh ballast layer with and without geosynthetics

cyclic waves. The node at the left corner of the bottom boundary of the section is considered as a pinned support (i.e., is restrained in both the vertical and horizontal directions). The left (axis of symmetry) and bottom boundaries are restrained in the horizontal and vertical directions, respectively. The top and right boundaries are unrestrained. A lateral distributed static load is applied to a movable steel wall of the prismoidal test chamber to simulate an effective confining pressure $\left(\sigma_{3}^{\prime}\right)$ of $7 \mathrm{kPa}$. The train load is simulated by applying an equivalent uniformly distributed vertical cyclic load on the tie. The cyclic deviator stress $\left(\Delta q_{\text {cyc }}\right)$ measured through databurst techniques at regular intervals during actual testing is applied to the FEM model [Fig. 7(a)]. Data-burst technique is defined as sampling of data bursts (1,500 readings in 1 second, sampling frequency $1,500 \mathrm{~Hz}$ ) over channels of pressure cells, potentiometers, and actuator position (recoverable or resilient strain) to evaluate the cyclic deviator stress $\left(\Delta q_{\text {cyc }}\right)$. The noise owing to electrical interference (background or white noise) was filtered by employing the discrete Fourier transform algorithm in MATLAB (Lackenby 2006). A total of 10,000 load cycles was applied in the finite-element analysis, and their computed results were compared with the experimental data at the same number of load cycles.

\section{Types of Soil Models}

The following sections describe the various soil models used for the railroad track materials. 

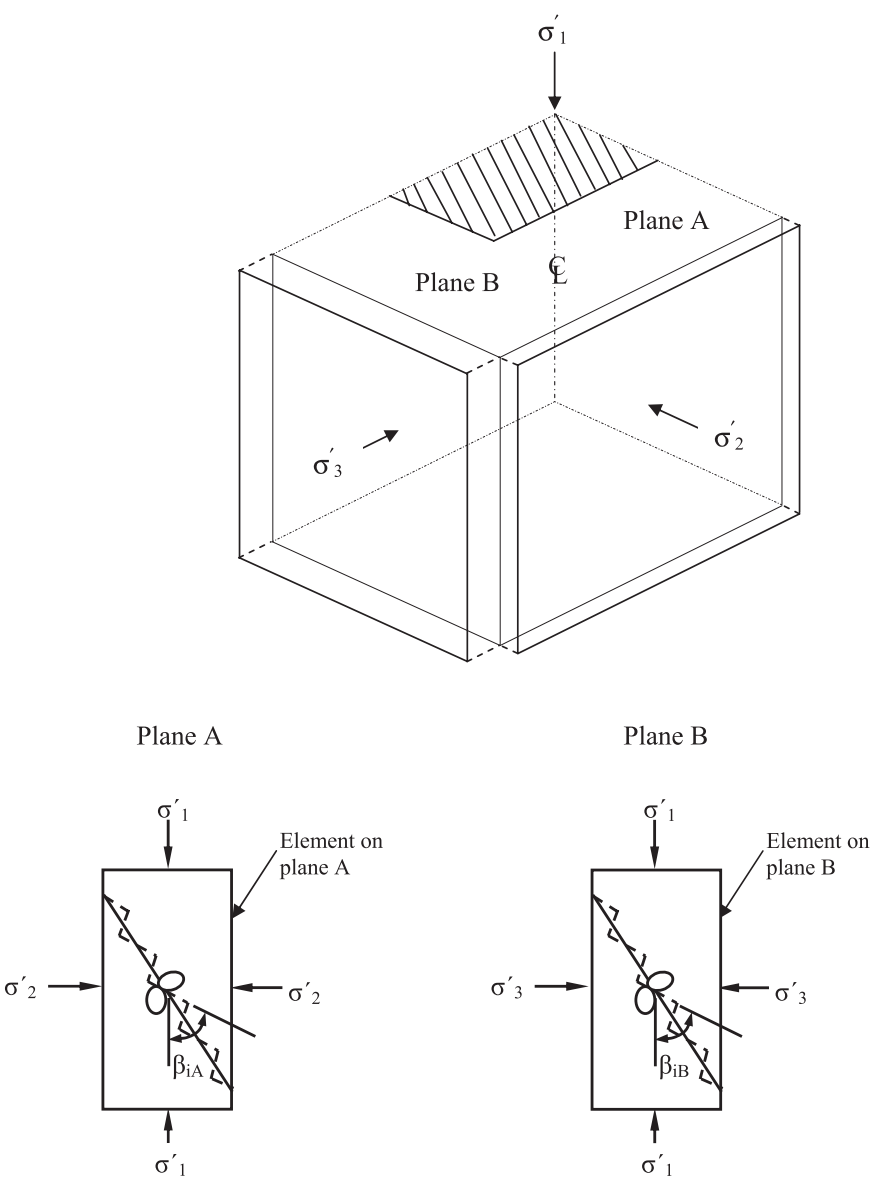

Fig. 6. Derivation of prismoidal dilatancy based on contact forces and deformations in a biaxial state

\section{Hardening Soil Model for Ballast}

The hardening soil (HS) model is based on isotropic hardening plasticity appropriate to simulate the strain-hardening behavior of railroad ballast subjected to repeated load cycles. The HS model includes material dilatancy, as proposed by Rowe (1962). Complete details of the stress-dependent stiffness moduli for primary, unloading, and reloading stress paths $\left(E_{50}, E_{u r}\right.$, and $E_{\text {oed }}$ can be found elsewhere (Schanz et al. 1999). As illustrated in Fig. 7(a), the long-term elastic response of materials subjected to cyclic loading is often characterized in terms of the resilient modulus $M_{r}$ $\left(=\Delta \sigma_{1 \text { cyc }}^{\prime} / \varepsilon_{1}^{e}\right.$, where $\varepsilon_{1}^{e}$ is the resilient component of vertical strain). To capture the hardening of $M_{r}$ observed in repeatedloading triaxial tests, the following relationship is used (Uzan 1985):

$$
E_{50}^{\mathrm{ref}}=M_{r}=k_{1} P_{a}\left(\frac{\theta}{P_{a}}\right)^{k_{2}}\left(\frac{\tau_{o c t}}{P_{a}}\right)^{k_{3}}
$$

where $M_{r}=$ resilient modulus in megapascals, $\theta=$ bulk stress in kilopascals, $\tau_{\text {oct }}=$ octahedral shear stress in kilopascals, $P_{a}=$ normalizing stress (atmospheric pressure: $101.325 \mathrm{kPa}$ at sea level), and $k_{1}, k_{2}$, and $k_{3}=$ coefficients obtained by fitting against the laboratory test results (Tables 4 and 5). For other materials such as subballast and subgrade, it is assumed that in the absence of hardening, their moduli do not change under cyclic loading, i.e., $E_{50}^{\text {ref }}=M_{r}$ (Howard and Warren 2009). The mobilized effective friction angle $\phi_{m}^{\prime}$ during the loading-reloading phase is expressed in terms of the effective major and minor principal stresses according to the Mohr-Coulomb failure criterion:

$$
\sin \phi_{m}^{\prime}=\frac{\sigma_{1}^{\prime}-\sigma_{3}^{\prime}}{\sigma_{1}^{\prime}+\sigma_{3}^{\prime}}
$$

For low confining pressure, a very high friction angle for ballast (up to $65^{\circ}$ ) is not surprising (Tables 4 and 5). The nonassociated plastic flow rule incorporating the rate of particle breakage during shearing in $2 \mathrm{D}$ space is represented by

$$
d \varepsilon_{v}^{p}=\left[1-\left(\frac{\sigma_{1}^{\prime}}{\sigma_{3}^{\prime}}\right) \tan ^{2}\left(45-\frac{\phi_{f}^{\prime}}{2}\right)+\kappa\left(\frac{d \mathrm{BBI}}{\sigma_{3}^{\prime} d \varepsilon_{1}^{p}}\right)\left(1-\sin \phi_{f}^{\prime}\right)\right] d \varepsilon_{1}^{p}
$$

The mobilized dilatancy angle $\psi_{m}$ during the loading-reloading phase is expressed as

$$
\sin \psi_{m}=\frac{d \varepsilon_{1}^{p}+x d \varepsilon_{3}^{p}}{d \varepsilon_{1}^{p}-x d \varepsilon_{3}^{p}}=\frac{d \varepsilon_{v}^{p} / d \varepsilon_{1}^{p}}{2-\left(d \varepsilon_{v}^{p} / d \varepsilon_{1}^{p}\right)}
$$

where $x=1$ for plane strain and $x=2$ for triaxial test conditions. By incorporating the effect of particle breakage, $\psi_{m}$ can be expressed by substituting Eq. (15) into Eq. (16):

$$
\sin \psi_{m}=\frac{\left[1-\left(\frac{\sigma_{1}^{\prime}}{\sigma_{3}^{\prime}}\right)\left(\frac{1-\sin \phi_{f}^{\prime}}{1+\sin \phi_{f}^{\prime}}\right)+\kappa\left(\frac{d \mathrm{BBI}}{d \varepsilon_{1}^{p}}\right)\left(\frac{1}{\sigma_{3}^{\prime}}\right)\left(1-\sin \phi_{f}^{\prime}\right)\right]}{\left[1+\left(\frac{\sigma_{1}^{\prime}}{\sigma_{3}^{\prime}}\right)\left(\frac{1-\sin \phi_{f}^{\prime}}{1+\sin \phi_{f}^{\prime}}\right)-\kappa\left(\frac{d \mathrm{BBI}}{d \varepsilon_{1}^{p}}\right)\left(\frac{1}{\sigma_{3}^{\prime}}\right)\left(1-\sin \phi_{f}^{\prime}\right)\right]}
$$

It is interesting to know that the proposed modified stress-dilatancy relationship reduces to Rowe's stress-dilatancy relationship when particle breakage is ignored. Further details of the HS material parameters and breakage parameters are given in Tables 4 and 5 . All six tests had different values because at a given number of loading cycles unreinforced ballast (Test 1), ballast with one geosynthetic (Tests 2, 3, and 4), and ballast with two geosynthetics (Tests 5 and 6) showed different dilation characteristics and peak stress values. Thus, even for the same ballast, the change of interface and boundary conditions can give different apparent properties (Tables 4 and 5). To be more specific, the improved performance of ballast owing to placement of geosynthetics is captured through (1) increased internal friction angle of the ballast (Tables 4 and 5), (2) increased global interface friction [Eq. (18)], (3) increased resilient modulus (Tables 4 and 5), and (4) reduced dilation (Tables 4 and 5). Some slight differences are also associated with slight alterations associated with identical sample preparation. This is so because all these large prismoidal specimens $(0.8 \times 0.6 \times 0.6 \mathrm{~m})$ contained slightly different particle shapes and sizes. Even if the PSD curves were kept uniform and as close as possible to each other in gradation, still it would be very difficult to ensure very similar particle shapes for every test specimen owing to the varied geometries (angular and/or irregular) of freshly blasted coarse aggregates. Given this inevitable and significant variation in angularity, it is common for large-scale coarse rockfill specimens to have slightly different properties (e.g., friction angle), unlike conventional smaller particles such as natural sands and gravels. Therefore, we have deliberately determined the relevant properties for each specimen (e.g., friction angle) as given in Tables 4 and 5. 


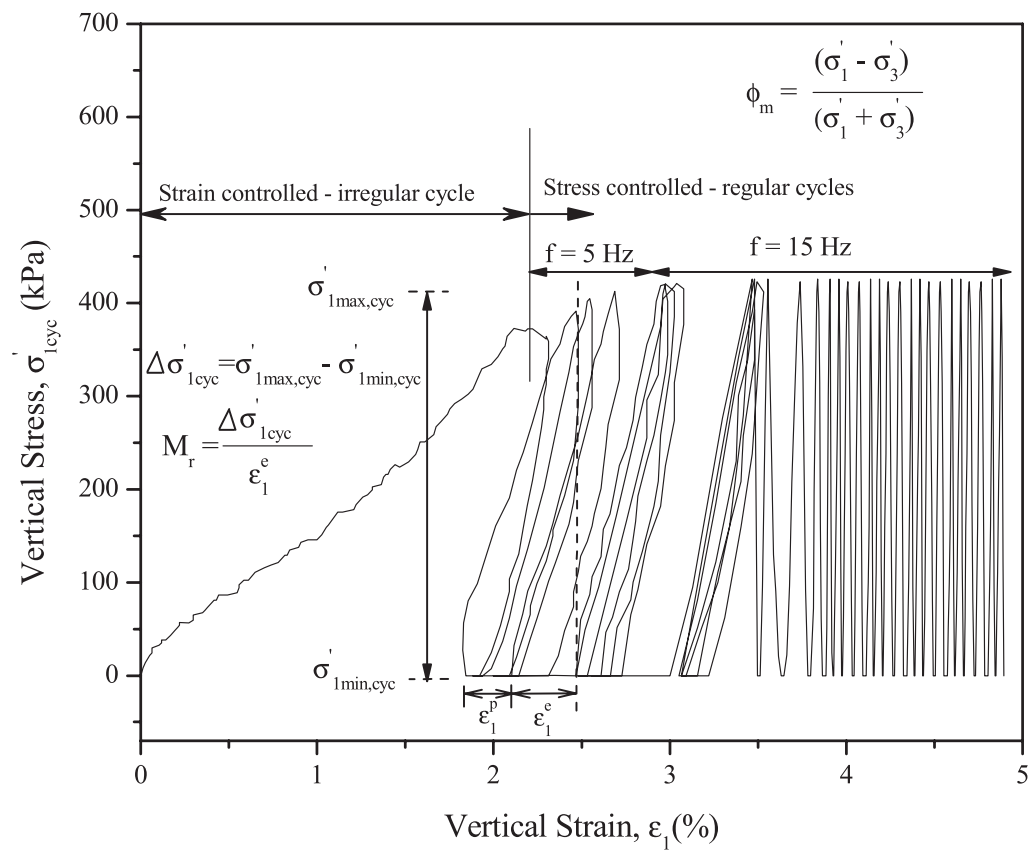

(a)

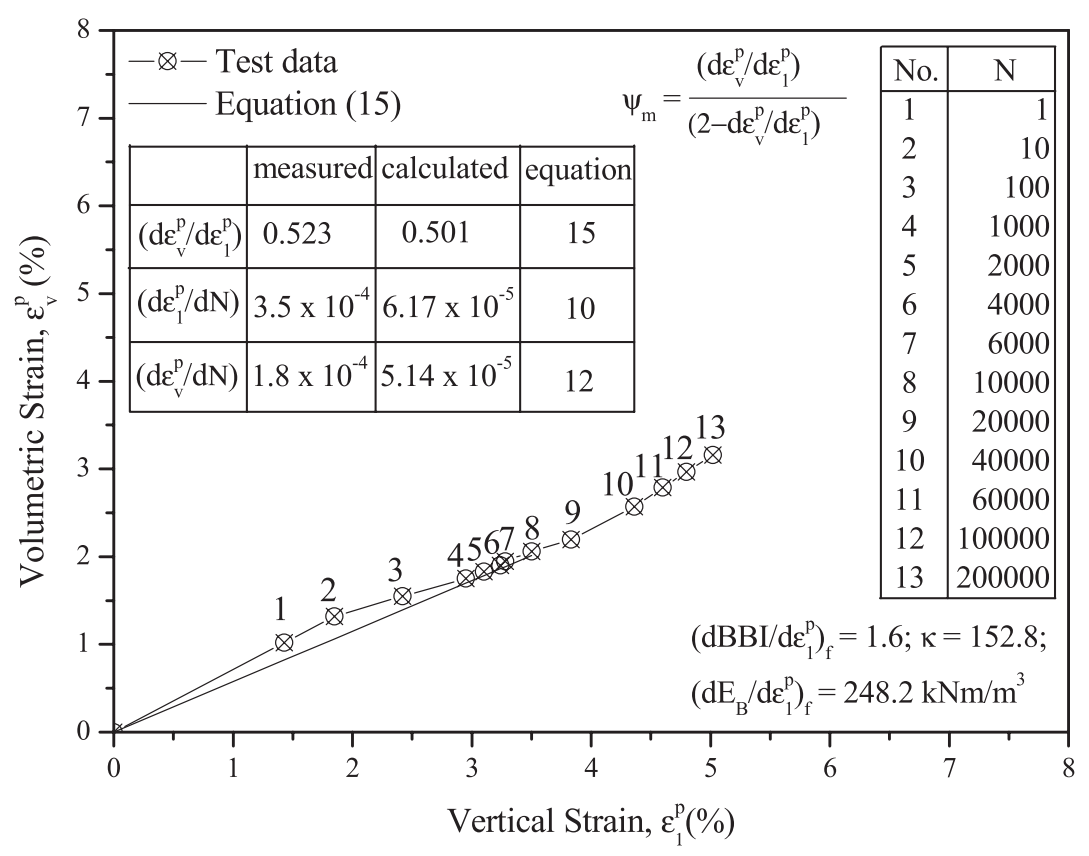

(b)

Fig. 7. Laboratory characterization for idealized hardening soil model of ballast: (a) cyclic stress-strain response; (b) flow rule

\section{Mohr-Coulomb Elastoplastic Model for Subballast and Subgrade}

Both the subballast and subgrade are represented with a standard Mohr-Coulomb model (linear elastic-perfectly plastic), whose primary function is to provide a representative foundation for the ballast. The MC model involves five key parameters (i.e., Young's modulus $E$, Poisson's ratio $\nu$, effective cohesion $c^{\prime}$, effective friction angle $\phi^{\prime}$, and dilatancy angle $\psi$ ). Subballast with the properties $E=140 \mathrm{MPa}, \nu=0.35, \psi=5^{\circ}$ and $\phi^{\prime}=35^{\circ}$ is considered. Subgrade with $E=60 \mathrm{MPa}, \nu=0.33, c^{\prime}=20 \mathrm{kPa}$ and $\phi^{\prime}=10^{\circ}$ is simulated.

\section{Linear Elastic Model and Interface Elements}

Wooden tie $\left(E=10 \mathrm{GPa}, \nu=0.15\right.$, and $\left.\gamma=17 \mathrm{kN} / \mathrm{m}^{3}\right)$ and steel boundary wall $\left(E=210 \mathrm{GPa}, \nu=0.15\right.$, and $\left.\gamma=77 \mathrm{kN} / \mathrm{m}^{3}\right)$ are considered as linear elastic. In addition, the linear elastic tension elements are used to model the geosynthetic layer. The shock mat $(E=6.12 \mathrm{MPa}$ and Rayleigh coefficients $\alpha=0.041$ and $\beta=0.002$ ) is simulated as a damping material (Nimbalkar et al. 2012). The axial stiffness of the geosynthetic is determined as $E A=F /(\Delta L / L)$, where $F$ is the applied axial force per unit width of test sample, and $\Delta L / L$ is the axial strain. The axial stiffness corresponding to $5 \%$ 


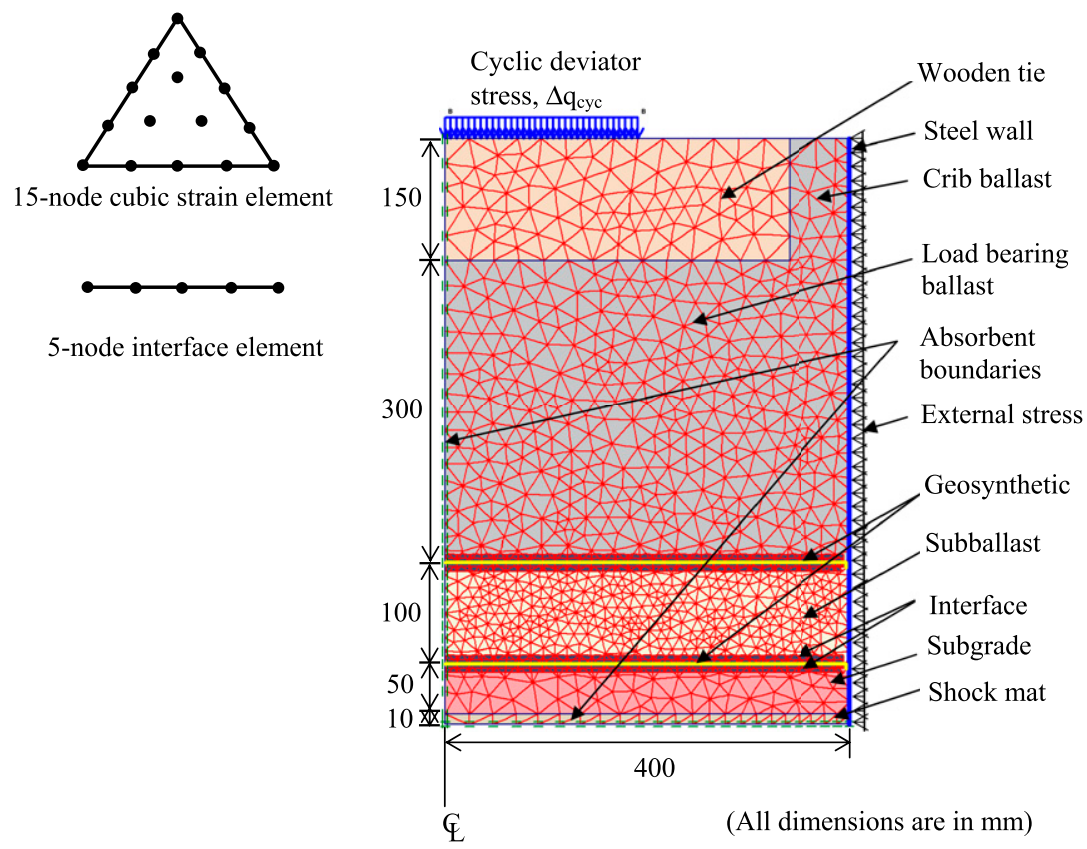

Fig. 8. Finite-element mesh discretization of typical test sample

Table 4. Parameters Used for Simulation of Hardening Soil Model for Ballast: Single Layer

\begin{tabular}{|c|c|c|c|c|c|c|}
\hline Material parameter & Symbol & Test 1 & Test 2 & Test 3 & Test 4 & Method of determination and other notes \\
\hline $\begin{array}{l}\text { Secant modulus (MPa) at } 50 \% \\
\text { strength for primary stress path }\end{array}$ & $E_{50}^{\mathrm{ref}}$ & 284.0 & 295.6 & 288.5 & 302.6 & Shown in Fig. 7(a) and using Eq. (13) \\
\hline $\begin{array}{l}\text { Tangent modulus (MPa) for } \\
\text { primary odometer stress path }\end{array}$ & $E_{\text {oed }}^{\text {ref }}$ & 284.0 & 295.6 & 288.5 & 302.6 & Same as the above (Schanz et al. 1999) \\
\hline $\begin{array}{l}\text { Stiffness modulus (MPa) for } \\
\text { unloading-reloading stress path }\end{array}$ & $E_{u r}^{\mathrm{ref}}$ & 852.0 & 886.8 & 865.5 & 907.7 & Equals $3 \times E_{50}^{\text {ref }}($ Schanz et al. 1999) \\
\hline Apparent friction angle (degrees) & $\phi^{\prime}$ & 64.0 & 64.4 & 64.2 & 64.6 & $\begin{array}{l}\text { Determined using Eq. (14) and also shown } \\
\text { in Fig. } 7 \text { (a) }\end{array}$ \\
\hline Angle of dilation (degrees) & $\psi$ & 19.5 & 15.8 & 15.5 & 14.8 & $\begin{array}{l}\text { Evaluated using Eq. (17) and also shown } \\
\text { in Fig. 7(b). }\end{array}$ \\
\hline $\begin{array}{l}\text { Rate of change of ballast breakage } \\
\text { index (BBI) at failure }\end{array}$ & $\left(d \mathrm{BBI} / d \varepsilon_{1}^{p}\right)_{f}$ & 1.6 & 1.5 & 1.4 & 1.3 & $\begin{array}{l}\text { Determined by the gradient of the plot of } \\
\text { BBI versus the major principal strain }\left(\varepsilon_{1}\right) \text {; } \\
\text { BBI is evaluated by sieving. }\end{array}$ \\
\hline $\begin{array}{l}\text { Rate of energy consumption } \\
\left(\mathrm{kNm} / \mathrm{m}^{3}\right) \text { at failure }\end{array}$ & $\left(d E_{B} / d \varepsilon_{1}^{p}\right)_{f}$ & 249.2 & 264.8 & 233.4 & 270.0 & $\begin{array}{l}\text { Determined by Eq. (7) for a given friction } \\
\text { angle } \phi^{\prime}\end{array}$ \\
\hline Empirical coefficient & $k$ & 153.4 & 182.2 & 163.0 & 204.6 & Determined by Eq. (8) \\
\hline Empirical coefficient & $k_{1}$ & 1.10 & 1.09 & 1.11 & 1.05 & Eq. (13) based on fitted laboratory data \\
\hline Empirical coefficient & $k_{2}$ & 0.21 & 0.20 & 0.18 & 0.14 & \\
\hline Empirical coefficient & $k_{3}$ & -1.00 & -1.20 & -1.15 & -1.35 & \\
\hline Empirical coefficient & $a^{\prime}$ & 0.14 & 0.11 & 0.12 & 0.08 & Eq. (10) based on fitted laboratory data \\
\hline Empirical coefficient & $b^{\prime}$ & 0.53 & 0.49 & 0.52 & 0.44 & \\
\hline
\end{tabular}

axial strain $(E A=360 \mathrm{kN} / \mathrm{m}$ for geogrid; $E A=391.4 \mathrm{kN} / \mathrm{m}$ for geocomposite) was determined from applicable test methods [ASTM D4632 (ASTM 2003a); ASTM D6637 (ASTM 2001a)] and from the information provided by the manufacturer. Zero-thickness fully bounded interface elements available in PLAXIS were used to model the frictional behavior between various layers and are simulated by five-node line elements. The geosynthetic material modeled here using the linear tension elements and the interface elements could not properly take into account the aggregate interlock mechanism of geogrids for providing local stiffness increase. These five-noded interface elements still can capture the interface strength through the effective friction angle at the interface, which will be lower than the maximum interparticle friction or dilation angle at low confining pressure. The role of this aggregate-geogrid interaction is captured through the strength-reduction factor $R_{\text {int }}$ obtained as

$$
\tan \phi_{\mathrm{int}}^{\prime}=R_{\mathrm{int}} \tan \phi_{m}^{\prime}
$$

where $\phi_{\text {int }}^{\prime}=$ effective friction angle of the interface. In this study, $R_{\text {int }}$ is assumed to be $1 / 2$ for the soil-geotextile interface and as $2 / 3$ for the soil-geogrid interface. 
Table 5. Parameters Used for Simulation of Hardening Soil Model for Ballast: Double Layer

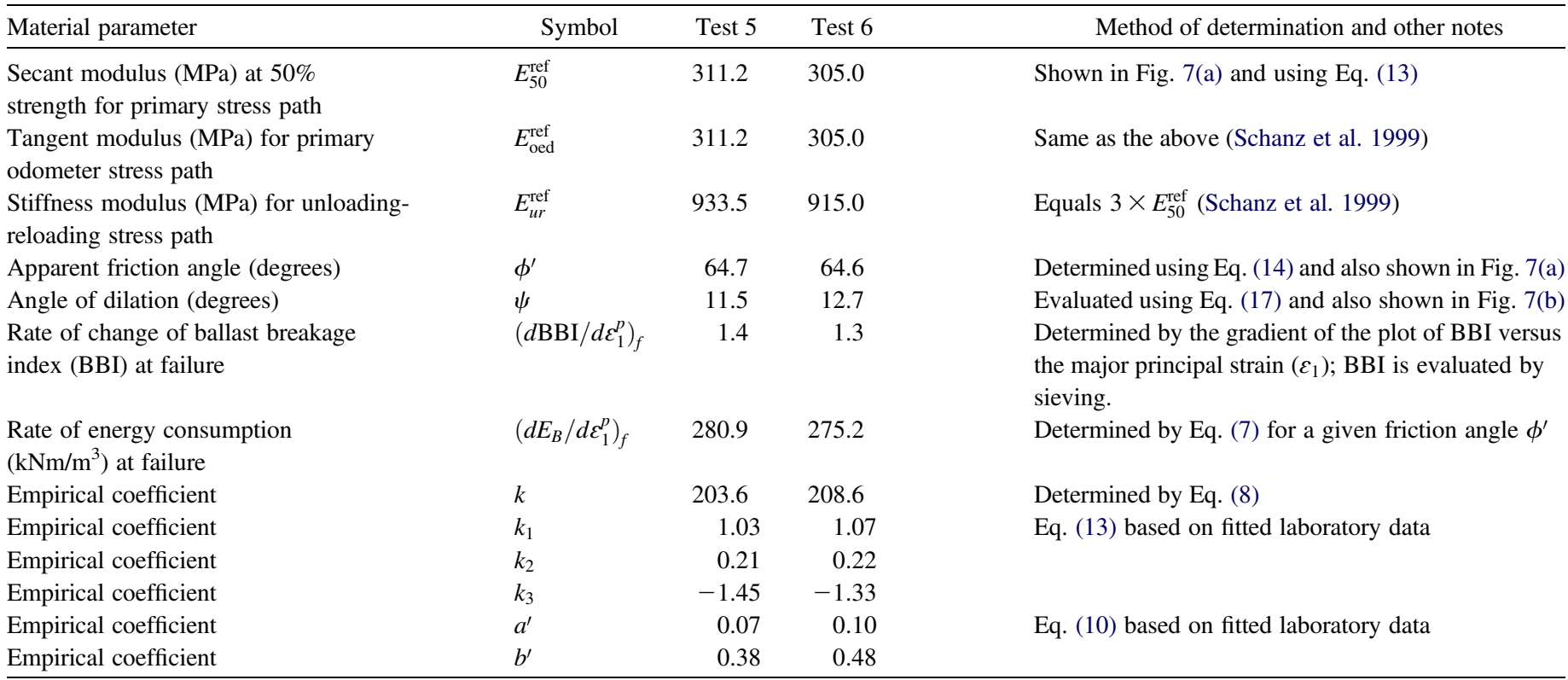

\section{Finite-Element Predictions}

Finite-element simulations were employed to predict the stressstrain behavior of railroad ballast subjected to cyclic loading. For brevity, only selected results are discussed. Fig. 9 shows the distribution of vertical stress $\left(\sigma_{v}^{\prime}\right)$ of fresh ballast along the tie at different depths. A nonuniform stress pattern is predicted at all the interfaces. Vertical stresses at the ballast, subballast, and subgrade surfaces are the largest approximately beneath the rail seat. Fig. 9 also shows a comparison of the results of this study with the simplified elasticity-based approaches commonly practiced among rail industries in Australia, such as MULTA [three-dimensional equations of linear elasticity for multi-layered systems (Kennedy and Prause 1978)], PSA [Fourier series for linear elastic behavior of materials, reviewed by Adegoke et al. (1979)], and ILLI-TRACK [finite element method using non-linear elastic material behavior (Tayabji and Thompson 1976)]. A wheel load of $145 \mathrm{kN}$, a ballast depth of $380 \mathrm{~mm}$, and a subballast depth of $150 \mathrm{~mm}$ were considered in MULTA, PSA, and ILLI-TRACK (Adegoke et al. 1979). It is evident that the FEM model predicts the vertical stress along the tie at different depths quite well in relation to the observed stress measuring using pressure cells in the laboratory. The FEM predictions are significantly different from the elastic analyses using MULTA, $P S A$, and ILLI-TRACK, which do not consider the actual cyclic nature of wheel loading, Furthermore, the values of vertical displacement $\left(S_{v d}\right)$ predicted by the FEM model show only a slight deviation from the laboratory data (Fig. 10). A nonuniform displacement pattern is predicted along the tie at different depths. The vertical deformation of ballast $\left(S_{v}\right)$ is calculated by differentiating the vertical displacements between the upper and lower surfaces of the ballast, respectively. The measured value of $S_{v}$ of $10.51 \mathrm{~mm}$ at the edge of the tie compares well with the predicted value of $9.98 \mathrm{~mm}$. A slight increase of $S_{v d}$ at the edge of the tie can be attributed to a reduced lateral restraint, as was confirmed previously though fullscale field studies (Indraratna et al. 2010a).

Fig. 11 shows the distribution of vertical displacement $\left(S_{v d}\right)$ and lateral displacement $\left(S_{h d}\right)$ along the depth of model track. It can be seen that geosynthetics substantially reduced the vertical and lateral displacements of ballast. The lateral-displacement values predicted by the current $2 \mathrm{D}$ elastoplastic analysis show a slight deviation from

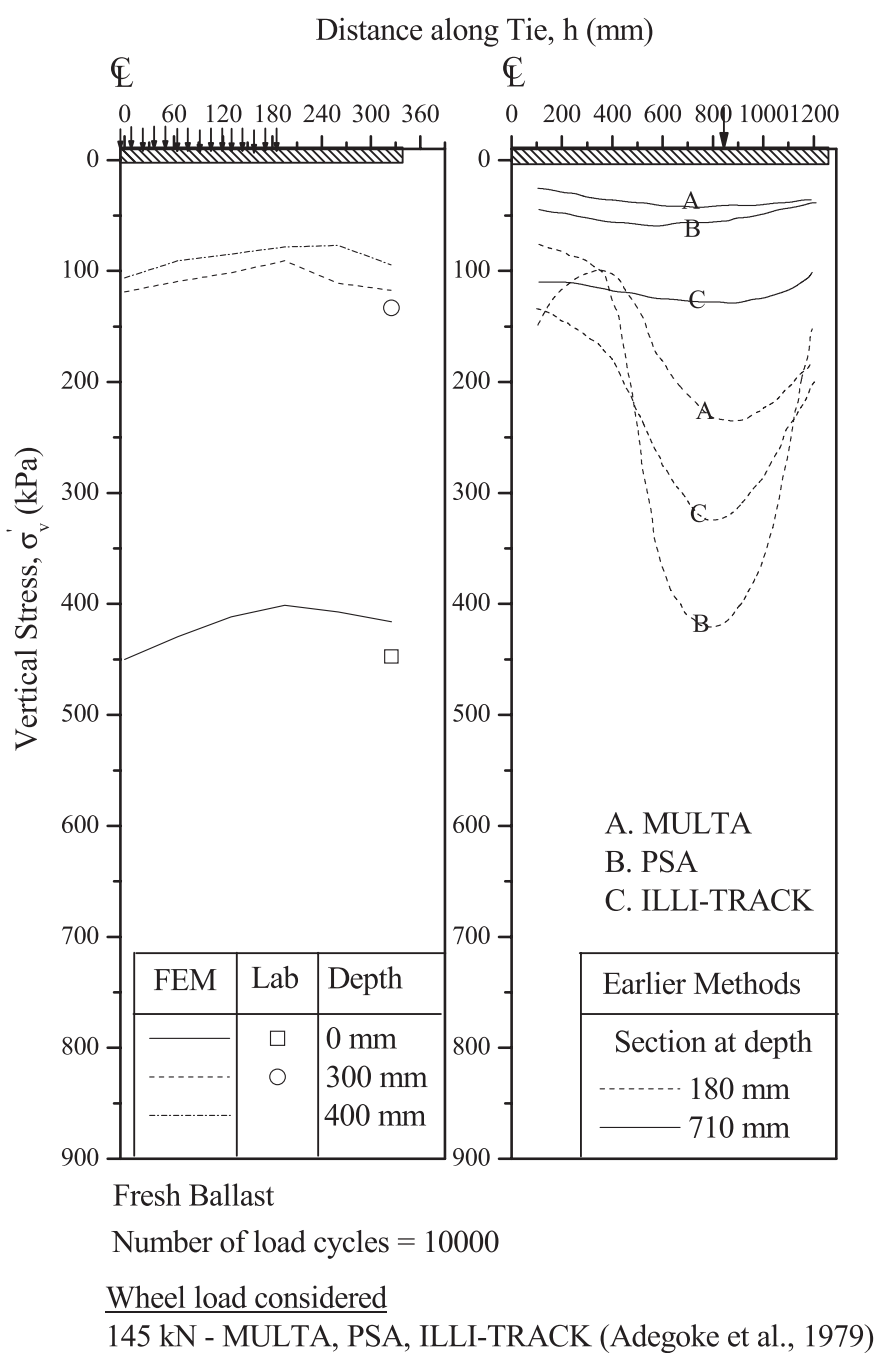

Fig. 9. Distribution of vertical stress $\left(\sigma_{v}^{\prime}\right)$ along tie: FEM predictions versus test results 


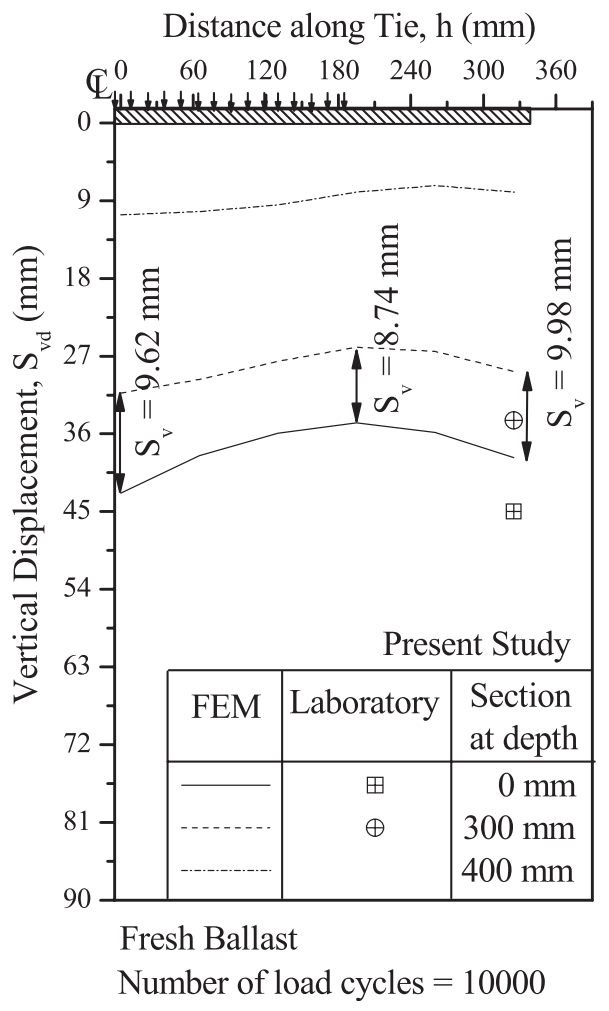

Fig. 10. Distribution of vertical displacement $\left(s_{v d}\right)$ along tie: FEM predictions versus test results

the measured strains. One possible reason is that particle breakage at intermediate loading cycles is not considered here; it was assessed only at the end of test. To further validate the FEM model, the permanent deformations are linked to the number of loading cycles. The variations in vertical $\left(S_{v}\right)$ and lateral deformation $\left(S_{h}\right)$ of ballast with number of loading cycles $(N)$ is presented in Fig. 12. It is evident that the 2D elastoplastic FEM analysis is able to capture the nonlinear variation of permanent deformation response of ballast with $N$. These results clearly show that the use of geosynthetic reinforcement contributes to decreased track settlement and lateral strains and improved track stability.

\section{Limitation of This Study}

Given the limited height of the triaxial chamber $(600 \mathrm{~mm})$, the subgrade thickness had to be curtailed. The $50-\mathrm{mm}$ subgrade is not realistic compared with the much higher thicknesses of subgrade seen in the field. However, as indicated earlier, these laboratory tests were conducted with the specific purpose of comparing the relative behavior when different geosynthetic types are used (i.e., geogrids, geotextiles, and geocomposites). The maximum triaxial height of specimens is $600 \mathrm{~mm}$, of which the most important ballast layer had to be $300 \mathrm{~mm}$, as in the field (Australian railroad tracks), with the crib ballast taking $150 \mathrm{~mm}$ to confine the sleeper. Therefore, the thickness of capping (subballast) and subgrade layers had to be reduced to 100 and $50 \mathrm{~mm}$, respectively. Because all the tests still had the same subgrade thickness $(50 \mathrm{~mm})$, direct comparison of the influence of these different geosythetics on the ballast behavior still could be made. Indeed, using a thinner subgrade thickness would affect the overall compliance. In the field, the lateral movement of subballast would be less than that of ballast. This decreased thickness of material beneath the ballast would induce more lateral displacement in the subballast than what would be normally expected in the field.
We selected the 2D (plane-strain) PLAXIS analysis because the 3D analysis in PLAXIS could not accommodate cyclic loading. We accept that the experimental setup was not $2 \mathrm{D}$ plane strain because the strains in the longitudinal direction could not always be maintained at zero. In several railroad tracks we have measured longitudinal strains to be one-quarter to one-half the transverse strains, even along relatively straight track sections (e.g., Singleton track near Newcastle City, Bulli track near Wollongong City). Pronounced 3D behavior is seen when approaching turnouts and curves. As shown in Figs. 10-12, the comparison between the PLAXIS 2D numerical data and the experimental observations clearly elucidates this discrepancy. If a proper 3D analysis could be done with cyclic loads, then this discrepancy would be much less. However, the key objective of this study was to compare the relative behavior of different geosynthetics under the same test conditions. Although the 2D PLAXIS analysis was not an accurate match to the laboratory data, still the relative behavior between different geosynthetics could be studied using both the numerical and experimental procedures.

We have chosen the elastoplastic continuum modeling approach in this study to simulate the overall plastic deformation and degradation response of railroad ballast subjected to a large number of loading cycles. In this study, the FEM approach can simulate loading up to 10,000 loading cycles, whereas the discrete-element modeling (DEM) approach cannot handle more than a few thousand cycles [Particle Flow Code (PFC2D; PFC3D)]. Therefore, for large numbers of cycles that are appropriate for rail track traffic, the FEM approach was considered to be more suitable than DEM. However, we accept that DEM would be more suitable for modeling the geogrids and particles interlock compared with FEM. The current FEM model on its own cannot accurately simulate the local stiffness increase by the aggregate-geogrid interlock. This is a limitation of this analysis. For better insight into the aggregate-geogrid interlock mechanism, the DEM approach has to be used, which is not within the scope of this paper.

\section{Conclusions}

A series of cyclic drained tests was conducted on fresh railroad ballast with biaxial geogrid, nonwoven geotextile, and geocomposite inclusions placed at the ballast-subballast and subballast-subgrade interfaces. The biaxial geogrid and nonwoven geotextile demonstrated their effectiveness by reducing settlement and the movement of particles under cyclic loads, as well as reducing grain breakage. As expected, the geogrid was more effective than the geotextile owing to a strong mechanical interlock between the grid apertures and particles of ballast. It was concluded that the biaxial geogrid would be a suitable reinforcement to be placed below the ballast for overall railroad track stabilization. However, a biaxial geogrid was not an effective separator when used below the subballast layer unless it was placed in conjunction with a geotextile. On the basis of this study, the geocomposite was shown to be very effective at controlling both strain and particle breakage. It also was demonstrated that dual-layer reinforcements, i.e., geogrid at the ballast-subballast interface and geocomposite at the subballast-subgrade interface, are better at reducing settlement than single-layer reinforcements.

The results of the experimental tests were compared with the predictions of a 2D cyclic elastoplastic FEM analysis (PLAXIS). A numerical analysis captured the plane-strain response of ballast using an isotropic hardening model in conjunction with a modified stress-dilatancy theory that incorporated the effect of particle breakage. The results indicated that the 2D (plane-strain) FEM model could predict the stress-strain-degradation of a reinforced and unreinforced model railroad track system subjected to cyclic 


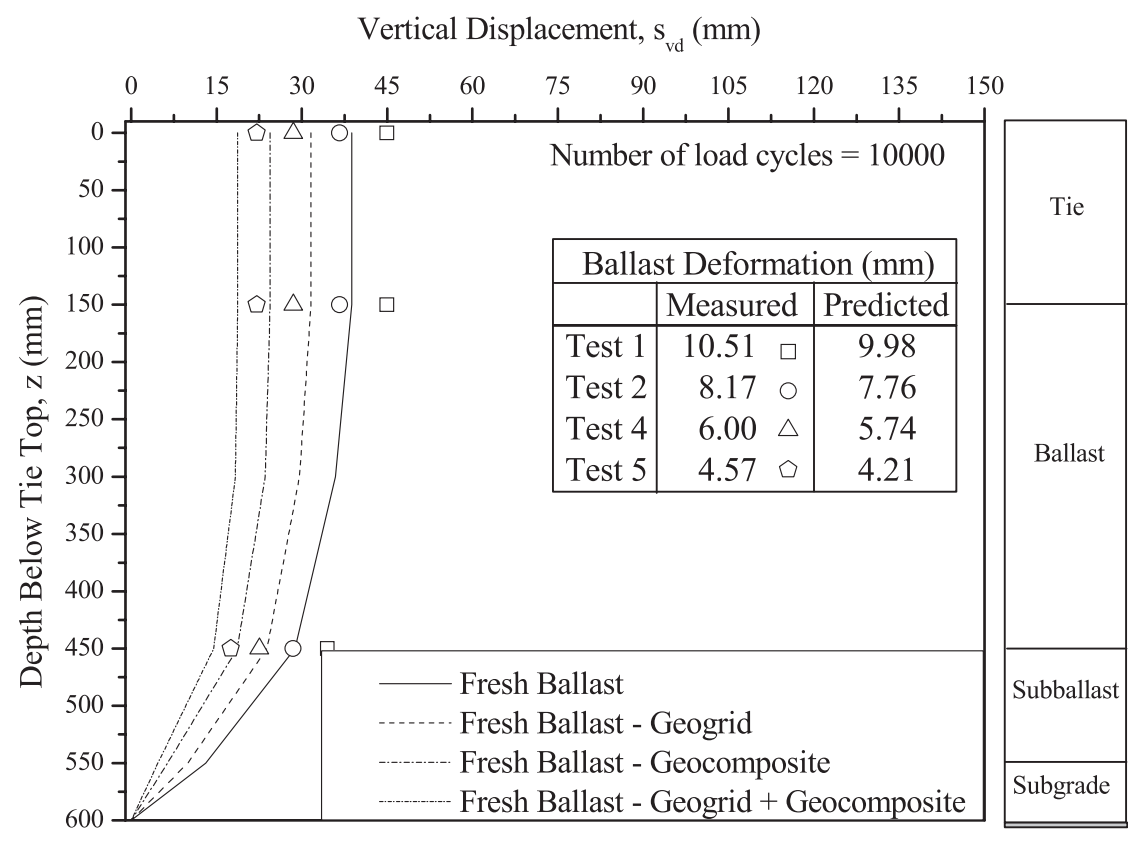

(a)

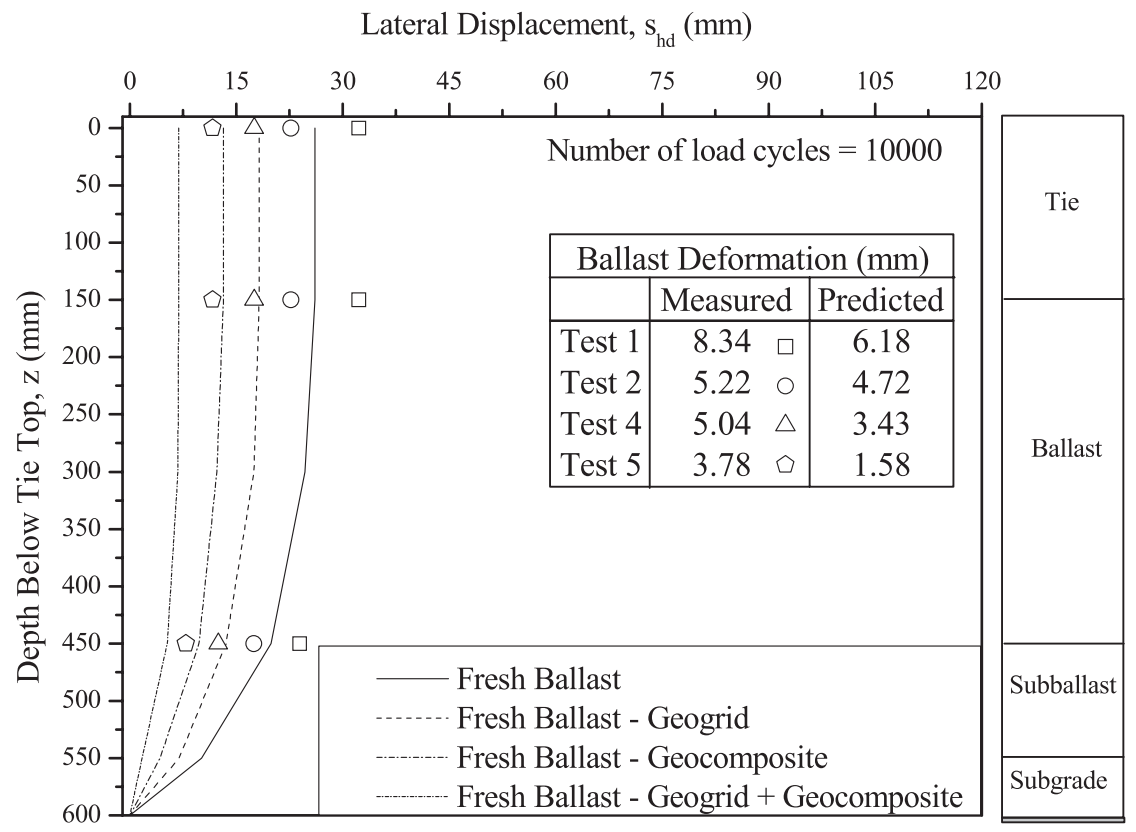

(b)

Fig. 11. Comparison of FEM predictions with test results: (a) vertical displacement $\left(S_{v d}\right)$; (b) lateral displacement $\left(S_{h d}\right)$

loading with reasonable accuracy. The FEM model also could simulate the relative performance of single and dual layers of geosynthetics placed in the model track. The FEM model is further validated by modeling the permanent deformation versus number of loading cycles.

Given that railroad ballast subjected to large cyclic loads (e.g., heavy-axle trains operating at high speeds) inevitably will be damaged, the use of appropriate geosynthetics provides an effective and environmentally sound solution for optimizing track performance and reducing maintenance costs. This study also suggests that the correct placement of geosynthetics in relation to the stabilized interfaces will play a vital role in the overall behavior of ballasted track. However, the role of geosynthetics for varied subgrade soils and the influence of other variables such as aperture size, stiffness, and tensile strength have not been elucidated within the scope of this study. Fully instrumented field studies are currently being launched by the authors near the city of Newcastle to capture the effects of different types of geosynthetics along variable ground conditions, and the data from this field study will be reported in a subsequent paper.

\section{Acknowledgments}

The authors express their sincere gratitude to Techfab Industries, Ltd. (India), which supplied the geosynthetic materials used in this study. The authors thank the Cooperative Research Centre (CRC) 
Number of Load Cycles, $\mathrm{N}$

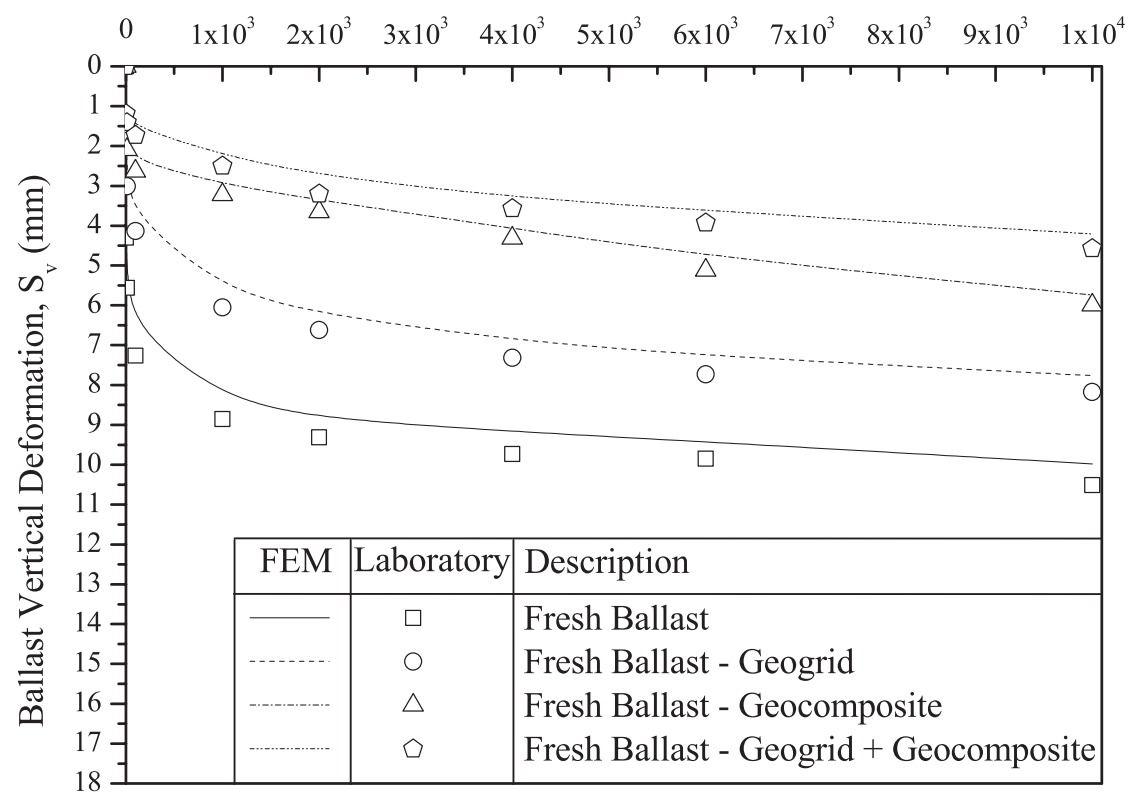

(a)

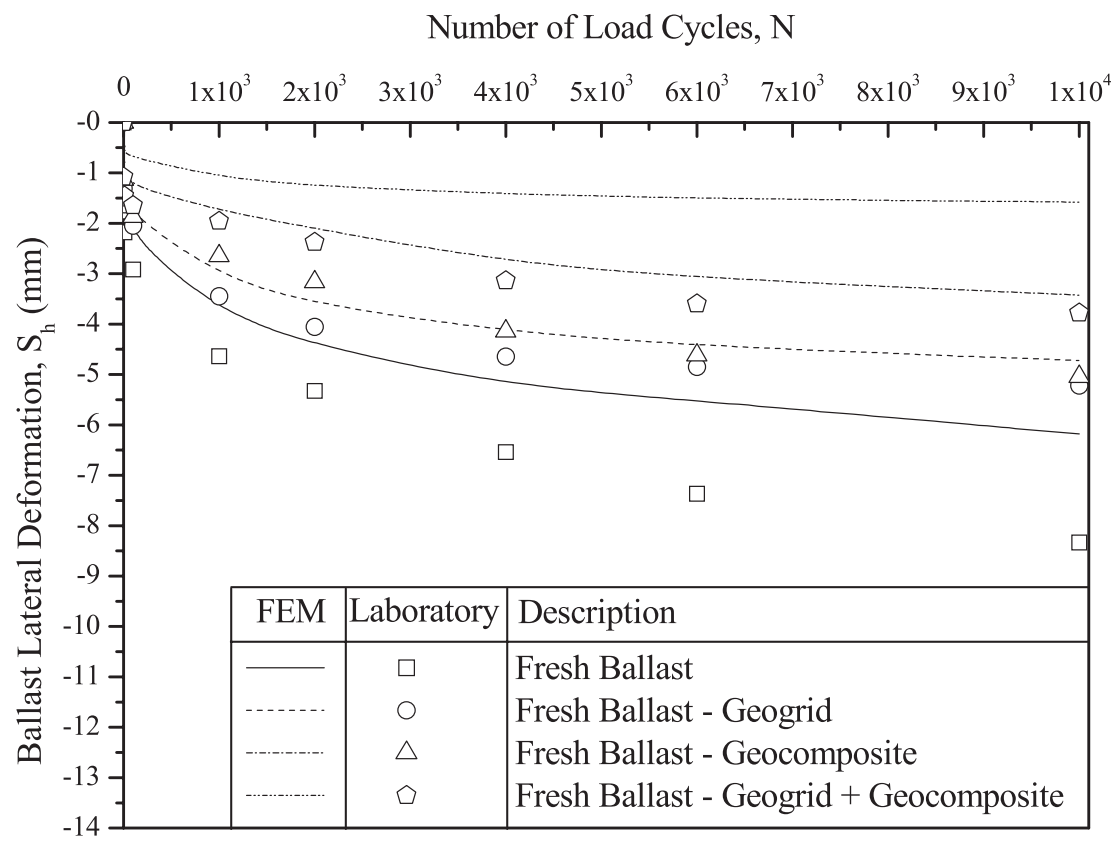

(b)

Fig. 12. Comparison of FEM predictions with test results for increasing number of load cycles: (a) vertical deformation $\left(S_{v}\right)$; (b) lateral deformation $\left(S_{h}\right)$

for Rail Innovation (Australia) and Railcorp (Sydney) for continuous support.

\section{References}

Adegoke, C. W., Chang, C. S., and Selig, E. T. (1979). "Study of analytical models for track support systems." Transportation Research Record 733, Transportation Research Board, Washington, DC, 1220.

Anderson, W. F., and Fair, P. (2008). "Behaviour of railroad ballast under monotonic and cyclic loading." J. Geotech. Geoenviron. Eng., 134(3), 316-327.
ASTM. (1999). "Standard test method for deterioration of geotextiles from exposure to ultravoilet light and water (Xenon-Arc type apparatus)." D4355, West Conshohocken, PA.

ASTM. (2001a). "Standard test method for determining tensile properties of geogrids by the single or multi-rib tensile method." D6637, West Conshohocken, PA.

ASTM. (2001b). "Standard test method for hydraulic bursting strength of textile fabrics-diaphragm bursting strength tester method." D3786, West Conshohocken, PA.

ASTM. (2001c). "Standard test method for index puncture resistance of geotextiles, geomembranes, and related products." D4833, West Conshohocken, PA. 
ASTM. (2003a). "Standard test method for grab breaking load and elongation of geotextiles." D4632, West Conshohocken, PA.

ASTM. (2003b). "Standard test method for measuring mass per unit area of geotextiles." D5261, West Conshohocken, PA.

ASTM. (2004a). "Standard test method for determining apparent opening size of a geotextile." D4751, West Conshohocken, PA.

ASTM. (2004b). "Standard test method for trapezoid tearing strength of geotextiles." D4533, West Conshohocken, PA.

ASTM. (2004c). "Standard test methods for water permeability of geotextiles by permittivity." D4491, West Conshohocken, PA.

ASTM. (2006). "Standard test method for measuring nominal thickness of geosynthetics." D5199, West Conshohocken, PA.

Brown, S. F., Kwan, J., and Thom, N. H. (2007). "Identifying the key parameters that influence geogrid reinforcement of railway ballast." Geotextile Geomembr., 25(6), 326-335.

Esveld, C. (2001). Modern railway track, MRT Productions, Zaltbommel, Netherlands.

Giroud, J. P., and Han, J. (2004a). "Design method for geogrid-reinforced unpaved roads. I: Development of design method." J. Geotech. Geoenviron. Eng., 130(8), 775-786.

Giroud, J. P., and Han, J. (2004b). "Design method for geogrid-reinforced unpaved roads. II: Calibration and applications." J. Geotech. Geoenviron. Eng., 130(8), 787-797.

Göbel, C. H., Weisemann, U. C., and Kirschner, R. A. (1994). "Effectiveness of a reinforcing geogrid in a railway subbase under dynamic loads." Geotextile Geomembr., 13(2), 91-99.

Howard, I. L., and Warren, K. A. (2009). "Finite-element modeling of instrumented flexible pavements under stationary transient loading." J. Transp. Eng., 135(2), 53-61.

Indraratna, B., Ionescu, D., and Christie, D. (1998). "Shear behavior of railway ballast based on large-scale triaxial tests." J. Geotech. Geoenviron. Eng., 124(5), 439-449.

Indraratna, B., Khabbaz, H., Salim, W., and Christie, D. (2006). "Geotechnical properties of ballast and the role of geosynthetics in rail track stabilization." Ground Improv., 10(3), 91-101.

Indraratna, B., Lackenby, J. and Christie, D. (2005). "Effect of confining pressure on the degradation of ballast under cyclic loading." Geotechnique, 55(4), 325-328.

Indraratna, B., Nimbalkar, S., Christie, D., Rujikiatkamjorn, C., and Vinod, J. S. (2010a). "Field assessment of the performance of a ballasted rail track with and without geosynthetics." J. Geotech. Geoenviron. Eng., 136(7), 907-917.

Indraratna, B., and Salim, W. (2002). "Modelling of particle breakage of coarse aggregates incorporating strength and dilatancy." Proc. Inst. Civil Eng. Geotech. Engrg., 155(4), 243-252.

Indraratna, B., and Salim, W. (2003). "Deformation and degradation mechanics of recycled ballast stabilised with geosynthetics." Soils Found. 43(4), 35-46.

Indraratna, B., Salim, W., and Rujikiatkamjorn, C. (2011). Advanced rail geotechnology: Ballasted track, CRC Press/Balkema, Rotterdam, Netherlands.

Indraratna, B., Shahin, M. A., and Salim, W. (2007). "Stabilising granular media and formation soil using geosynthetics with special reference to railway engineering." Ground Improv., 11(1), 27-44.

Indraratna, B., Thakur, P. K., and Vinod, J. S. (2010b). "Experimental and numerical study of railway ballast behavior under cyclic loading." Int. J. Geomech., 10(4), 136-144.

Jeffs, T., and Marich, S. (1987). "Ballast characteristics in the laboratory." Proc., Conf. on Railway Engineering, Institution of Engineers Australia, Perth, Australia, 141-147.

Jiroušek, O., et al. (2010). "Numerical modelling of the reinforcing effect of geosynthetic material used in ballasted railway tracks., Proc., Inst. Mech Eng. F: J. Rail Rapid Transit, 224(4), 259-267.

Kennedy, J., and Prause, R. (1978). "Development of multilayer analysis model for tie-ballast track structures." Transportation Research Record 694, Transportation Research Board, Washington, DC, 39-47.

Koerner, R. M. (1990). Designing with geosynthetics, Prentice-Hall, Englewood Cliffs, NJ.

Kwon, J., Tutumluer, E., and Al-Qadi, I. L. (2009). "Validated mechanistic model for geogrid base reinforced flexible pavements." J. Transp. Eng., 135(12), 915-926.
Lackenby, J. (2006), "Triaxial behavior of ballast and the role of confining pressure under cyclic loading." Ph.D. thesis, Univ. of Wollongong, Wollongong City, NSW, Australia.

Lackenby, J., Indraratna, B., McDowell, G., and Christie, D. (2007). "Effect of confining pressure on ballast degradation and deformation under cyclic triaxial loading." Geotechnique, 57(6), 527-536.

Lade, P. V. (2006). "Assessment of test data for selection of 3D failure criterion for sand." Int. J. Numer. Anal. Methods Geomech., 30(4), 307-333.

Li, D., and Selig, E. T. (1998). "Method for railroad track foundation design. I: Development." J. Geotech. Geoenviron. Eng., 124(4), 316-322.

Lu, M., and McDowell, G. R. (2006). "Discrete element modelling of ballast abrasion." Geotechnique, 56(9), 651-655.

Matsuoka, H., and Nakai, T. (1982). "A new failure criterion for soils in three dimensional stress." Proc., Conf. on Deformation and Failure of Granular Materials, Vermeer PA, et al. (eds.), Delft, Netherlands, 253-263.

Montanelli, F., and Recalcati, P. (2003). "Geogrid reinforced railways embankments: Design concepts and experimental test results." Proc., IABSE Symp., Antwerp, Netherlands, 212-213.

Neidhart, T. (2001). "True-to-scale in situ tests determining dynamic performance of earthworks under high speed train loading." Proc., Geotechnics for Roads, Rail Tracks and Earth Structures, Vol. ETC11, ISSMGE, Rotterdam, Netherlands, 213-223.

Nimbalkar, S., Indraratna, B., Dash, S. K., and Christie, D. (2012). "Improved performance of railway ballast under impact loads using shock mats." J. Geotech. Geoenviron. Eng., 138(3), 281-294.

Particle flow code in two dimensions (PFC2D) 3.0. [Computer software]. Minneapolis, MN, Itasca Consulting Group, Inc.

Particle flow code in three dimensions (PFC3D) 3.1. [Computer software]. Minneapolis, MN, Itasca Consulting Group, Inc.

PLAXIS 2D 8.6 [Computer software]. Delft, Netherlands, PLAXIS BV.

Rail Infrastructure Corporation of New South Wales. (2001a). "Specification for supply of aggregate for ballast." T.S. 3402,Sydney, Australia.

Rail Infrastructure Corporation of New South Wales. (2001b)."Standard for formation capping material." T.S. 3422, Sydney, Australia.

Raymond, G. P. (2002). "Reinforced ballast behavior subjected to repeated load." Geotextile Geomembr., 20(1), 39-61.

Raymond, G. P., Gaskin, P. N., and Svec, O. (1975). "Selection and performance of railroad ballast." Railroad track mechanics and technology, Kerr, R., ed., Princeton, NJ, 369-385.

Raymond, G. P., and Ismail, I. (2003). "The effect of geogrid reinforcement on unbound aggregates." Geotextile Geomembr., 21(6), 355-380.

Rowe, P. K., and Jones, C. J. F. P. (2000). "Geosynthetics: Innovative materials and rational design." Proc., GEOENG 2000, Technomic, Lancaster, PA.

Rowe, P. W. (1962). "The stress-dilatancy relation for the static equilibrium of an assembly of particles in contact." Proc. R. Soc. Lond. A, 269(1339), 500-527.

Sato, Y. (1995). "Japanese studies on deterioration of ballasted track." Veh. Syst. Dyn., 24(Supp. 1), 197-208.

Schanz, T., and Vermeer, P. A. (1996). "Angles of friction and dilatancy of sand." Geotechnique, 46(1), 145-151.

Schanz, T., Vermeer, P. A., and Bonnier, P. G. (1999). "The hardening soil model: Formulation and verification." Proc., Plaxis Symp., Beyond 2000 in Comput. Geotech., Balkema, Rotterdam, Netherlands, 55-58.

Selig, E. T. and Waters, J. M., (1994). Track geotechnology and substructure management, Thomas Telford, London (reprint 2007).

Shin, E. C., Kim, D. H., and Das, B. M. (2002). "Geogrid-reinforced railroad bed settlement due to cyclic load." Geotech. Geol. Eng., 20(3), 261-271.

Standards Australia. (1996). "Aggregates and rock for engineering purposes. 7: Railway ballast.” AS 2758.7, New South Wales, Australia, 1996.

Suiker, A. S. J., and de Borst, R. (2003). "A numerical model for the cyclic deterioration of railway tracks." Int. J. Numer. Methods Engrg., 57(4), 441-470.

Tayabji, S., and Thompson, M. (1976). Program ILLI-TRACK: A finite element analysis of conventional railway support system: User's manual and program listing. Univ. of Illinois at Urbana-Champaign, Urbana, IL.

Timoshenko, S. P., and Goodier, J. N. (1970). Theory of elasticity, McGraw Hill, New York.

Ueng, T. S., and Chen, T. J. (2000). "Energy aspects of particle breakage in drained shear of sands." Geotechnique, 50(1), 65-72.

Uzan, J. (1985). "Characterization of granular material.” Transportation Research Record 1022, Transportation Research Board, Washington, DC, 52-59. 